"This document is the Accepted Manuscript version of a Published Work that appeared in final form in Inorganic Chemistry, copyright (C) American Chemical Society after peer review and technical editing by the publisher. To access the final edited and published work see [insert ACS Articles on Request author-directed link to Published Work, see http://pubs.acs.org/doi/abs/10.1021/ic5009076"

\title{
Synthesis, Characterization and Linkage Isomerism in Mononuclear Ruthenium Complexes Containing the New Pyrazolate Based ligand Hpbl
}

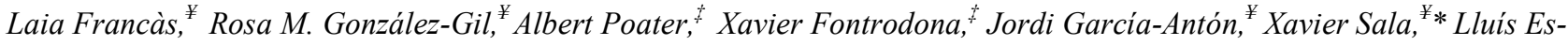
criche $^{* *}$ and Antoni Llobet ${ }^{\dagger, *} *$

\footnotetext{
${ }^{\dagger}$ Institute of Chemical Research of Catalonia (ICIQ), Av. Països Catalans 16, E-43007 Tarragona, Spain.

‡ Serveis tècnics de recerca, Institut de Química Computacional i Catàlisi and Departament de Química, Universitat de Girona, Campus de Montilivi, E-17071 Girona, Spain.

${ }^{¥}$ Departament de Química, Universitat Autònoma de Barcelona, Cerdanyola del Vallès, 08193, Barcelona, Spain
} 
ABSTRACT: A new tetradentate dinucleating ligand [1,1'-(4-methyl-1H-pyrazole-3,5-diyl)bis(1-(pyridin-2-yl)ethanol)] $(\mathrm{Hpbl})$ containing an $\mathrm{O} / \mathrm{N}$ mixed donor set of atoms has been synthesized and characterized by analytical and spectroscopic techniques. The $\mathrm{Ru}-\mathrm{Cl}$ and $\mathrm{Ru}$-aqua complexes containing this ligand of general formula $\left[\mathrm{Ru}{ }^{\mathrm{II}} \mathrm{X}(\mathrm{Hpbl})(\operatorname{trpy})\right]^{\mathrm{y}+}(\operatorname{trpy}=$ 2,2':6',2"-terpyridine; $\mathrm{X}=\mathrm{Cl}, \mathrm{y}=1 ; \mathrm{X}=\mathrm{H}_{2} \mathrm{O}, \mathrm{y}=2$ ) have been prepared and thoroughly characterized by spectroscopic and electrochemical techniques. The Ru-aqua complex $2^{2+}$, undergoes $\mathrm{N}->\mathrm{O}$ linkage isomerization as observed electrochemically and the related thermodynamic and kinetic parameters are extracted from cyclic voltammetry experiments together with DIGISIM, a CV simulation package. Under basic conditions an additional isomer is observed where the pyrazolyl group in the Hpbl ligand is replaced by the geminal pyridyl group. Further structural and electronic characterization of all the isomers has been carried out by mean of DFT calculations.

Keywords: Transition metal complexes, linkage isomerization, redox properties, Ru complexes, Pourbaix diagrams 


\section{Introduction}

Linkage isomerism has been used to build memory devices at the molecular level, which could provide the basis for the development of molecular electronics. ${ }^{1}$ Transition metal complexes with ambidentate motifs, able to change their coordination due to external stimuli (such as the application of the sufficient voltage to oxidize or reduce the metal center) are good candidates for this purpose. Different coordination environments produce different molecular properties, which allow the retention of information. Furthermore, in order to become good memory devices, those changes must be reversible. A wide number of ruthenium complexes containing sulfoxide ligands capable to carry out linkage isomerism have been reported, ${ }^{2}$ where their dynamic behavior is based on the higher affinity of $\mathrm{Ru}(\mathrm{II})$ and $\mathrm{Ru}(\mathrm{III})$ for $\mathrm{S}$ and $\mathrm{O}$ atoms respectively, in agreement with HSAB-Pearson theory. ${ }^{3}$ Another interesting example of Ru complexes containing the ambidentate ligand 1-[6-(2,2'bipyridyl)]-1-(2-pyridyl)-ethanol (bpy-py-OH) (Chart 1) has been recently described by Johansson and Lomoth, ${ }^{4}$ and exhibits fast electron-transfer-induced linkage isomerization.

During the last three decades, $\mathrm{Ru}$-aqua/oxo polypyridyl complexes have been used as oxidation catalysts due to their capacity to reach a wide range of oxidation states in a narrow potential range. ${ }^{5}$ The simultaneous proton and electron removal (PCET) allows increasing the metal oxidation state at relatively low potentials. ${ }^{6}$

Over the last few years, our group has focused its attention on the understanding and mastering of metal cooperation in chemical reactions using dinuclear metal-aqua/oxo complexes. ${ }^{7}$ For this purpose, the tetraaza dinucleating ligand 3,5-bis(2pyridyl)pyrazole [Hbpp, Chart 1] has been used as bridging ligand between two Ru metal centers and its catalytic properties have been established for oxidative transformations such as water oxidation and alkene epoxidation. ${ }^{8}$ When these Ruaqua/oxo polypyridyl species are involved in catalytic oxidative transformations, the metal center cycles typically within oxidations states II-V. ${ }^{9,10}$ The stabilization of all the oxidation states involved is of paramount importance in order to guarantee low kinetic barriers and thus catalyst viability.

Here on we report a new tetradentate bridging ligand, 1,1'-(4-methyl-1H-pyrazole-3,5-diyl)bis(1-(pyridin-2-yl)ethanol (Hpbl, Chart 1) potentially able to stabilize low and high oxidation states by adapting to the electronic demands of the metal center via linkage isomerism. In addition we also report two mononuclear Ru complexes containing this ligand of general formula $[\mathrm{RuX}(\mathrm{Hpbl})(\operatorname{trpy})]^{\mathrm{y}+}\left(\mathrm{X}=\mathrm{Cl}, \mathrm{y}=1 ; \mathrm{X}=\mathrm{H}_{2} \mathrm{O}, \mathrm{y}=2\right)$ and their linkage isomerization capacities.

Chart 1. Drawing of the ligands discussed in this work.

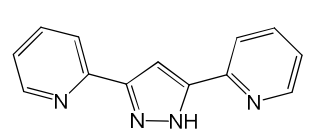

Hbpp<smiles>c1ccc(-c2cccc(-c3ccccn3)n2)nc1</smiles>

trpy<smiles>Cc1c(C(C)(O)c2ccccn2)n[nH]c1[C@H](O)c1ccccn1</smiles>

Hpbl<smiles>CC(O)(c1ccccn1)c1cccc(-c2ccccn2)n1</smiles>

bpy-py-OH 


\section{Experimental Section}

Materials. All reagents used in the present work were obtained from Sigma-Aldrich Chemical Co. and were used without further purification. Reagent grade organic solvents were obtained from SDS. $\mathrm{RuCl}_{3} \cdot 3 \mathrm{H}_{2} \mathrm{O}$ was supplied by Alfa Aesar and was used as received.

Preparations. The starting complex $\left[\mathrm{RuCl}_{3}(\operatorname{trpy})\right]^{11}$ and 1'-(4-methyl-1H-pyrazole-3,5-diyl)diethanone ${ }^{12}$ were prepared as previously described in the literature. All synthetic manipulations were routinely performed under nitrogen atmosphere using Schlenck tubes and vacuum line techniques.

1,1'-(4-Methyl-1H-pyrazole-3,5-diyl)bis(1-(pyridin-2-yl)ethanol) (Hpbl·1.5H $\mathbf{2} \mathbf{O})$. A sample of $0.91 \mathrm{~mL}(9.39 \mathrm{mmol}) \mathrm{of} 2-$ bromopyridine was dissolved in $100 \mathrm{~mL}$ of dry THF with vigorous stirring at $-78^{\circ} \mathrm{C}$. Then $6.2 \mathrm{~mL}$ of $n$-BuLi in hexane $(1.6$ M) were added drop by drop. After stirring the mixture during 30 minutes, $0.5 \mathrm{~g}$ (3.01 mmol) of 1'-(4-methyl-1H-pyrazole3,5-diyl)diethanone dissolved in $20 \mathrm{~mL}$ of dry THF were added slowly with a syringe pump. The resulting mixture was stirred during 2 hours at $-78{ }^{\circ} \mathrm{C}$ and then warmed up to $0{ }^{\circ} \mathrm{C}$, acidified with a $10 \% \mathrm{HCl}$ aqueous solution and finally neutralized (until $\mathrm{pH}=7$ ) with a $10 \% \mathrm{~K}_{2} \mathrm{CO}_{3}$ aqueous solution. During this process the color of the solution changed from brown to yellow and finally to orange. The resulting mixture was warmed up and extracted with $\mathrm{CHCl}_{3}(3 \mathrm{x} 100 \mathrm{~mL}) \mathrm{until}$ the extracted organic phase was colorless. The collected organic phases were mixed, dried with anhydrous $\mathrm{Na}_{2} \mathrm{SO}_{4}$ and evaporated until brown oil appeared. The oil was then purified by column chromatography using silica gel as stationary phase and ethyl acetate as eluent, giving the desired product in the fourth fraction as a 3.0:1.7 mixture of two diastereomers. Yield: $344 \mathrm{mg}(35 \%) .{ }^{1} \mathrm{H}$ NMR (360 MHz, acetonitrile- $\left.\mathrm{d}_{3}\right) \delta=8.49\left(\mathrm{ddd}, 2 \mathrm{H}_{3 \mathrm{~A}},{ }^{3} \mathrm{~J}_{3-2}=4.9 \mathrm{~Hz},{ }^{4} \mathrm{~J}_{3-1}=1.7 \mathrm{~Hz},{ }^{5} \mathrm{~J}_{3-6}=1.0 \mathrm{~Hz}\right.$ ), $8.48\left(\mathrm{ddd}, 2 \mathrm{H}_{3 \mathrm{~B}},{ }^{3} \mathrm{~J}_{3-2}=4.9 \mathrm{~Hz},{ }^{4} \mathrm{~J}_{3-1}=1.7 \mathrm{~Hz},{ }^{5} \mathrm{~J}_{3-6}=1.0 \mathrm{~Hz}\right), 7.72\left(\mathrm{ddd}, 2 \mathrm{H}_{1 \mathrm{~A}, \mathrm{~B}},{ }^{3} \mathrm{~J}_{1-6}=8.0 \mathrm{~Hz},{ }^{3} \mathrm{~J}_{1-2}=7.5 \mathrm{~Hz},{ }^{4} \mathrm{~J}_{1-3}=1.7 \mathrm{~Hz}\right), 7.31$ $\left(\mathrm{dt}, 2 \mathrm{H}_{6 \mathrm{~A}},{ }^{3} \mathrm{~J}_{6-1}=8.0 \mathrm{~Hz},{ }^{4} \mathrm{~J}_{6-2,3}=1.3 \mathrm{~Hz}\right), 7.28\left(\mathrm{dt}, 2 \mathrm{H}_{6 \mathrm{~B}},{ }^{3} \mathrm{~J}_{6-1}=8.0 \mathrm{~Hz},{ }^{4} \mathrm{~J}_{6-2,3}=1,0 \mathrm{~Hz}\right), 7.24\left(\mathrm{ddd}, 2 \mathrm{H}_{2 \mathrm{~B}},{ }^{3} \mathrm{~J}_{2-1}=7.5 \mathrm{~Hz},{ }^{3} \mathrm{~J}_{2-3}=4.9\right.$ $\left.\mathrm{Hz},{ }^{4} \mathrm{~J}_{2-6}=1.0 \mathrm{~Hz}\right), 7.24\left(\mathrm{ddd}, 2 \mathrm{H}_{2 \mathrm{~A}},{ }^{3} \mathrm{~J}_{2-1}=7.5 \mathrm{~Hz},{ }^{3} \mathrm{~J}_{2-3}=4.9 \mathrm{~Hz},{ }^{4} \mathrm{~J}_{2-6}=1.0 \mathrm{~Hz}\right), 5.23\left(\mathrm{~s}, 2 \mathrm{H}_{14 \mathrm{~B}}\right), 5.21\left(\mathrm{~s}, 2 \mathrm{H}_{14 \mathrm{~A}}\right), 1.79\left(\mathrm{~s}, 6 \mathrm{H}_{15 \mathrm{~B}}\right)$, $1.78\left(\mathrm{~s}, 6 \mathrm{H}_{15 \mathrm{~A}}\right), 1.43\left(\mathrm{~s}, 3 \mathrm{H}_{24 \mathrm{~A}}\right), 1.37\left(\mathrm{~s}, 3 \mathrm{H}_{24 \mathrm{~B}}\right) .{ }^{13} \mathrm{C}\{1 \mathrm{H}\}$ NMR $\left(100 \mathrm{MHz}\right.$, acetonitrile- $\left.\mathrm{d}_{3}\right) \delta=164.9\left(\mathrm{C}_{5 \mathrm{~A}}\right), 164.8\left(\mathrm{C}_{5 \mathrm{~B}}\right), 148.4$ $\left(\mathrm{C}_{3 \mathrm{~A}}\right), 148.3\left(\mathrm{C}_{3 \mathrm{~B}}\right), 138.1\left(\mathrm{C}_{1 \mathrm{~B}}\right), 138.1\left(\mathrm{C}_{1 \mathrm{~A}}\right), 123.2\left(\mathrm{C}_{2 \mathrm{~A}, \mathrm{~B}}\right), 121.0\left(\mathrm{C}_{6 \mathrm{~A}, \mathrm{~B}}\right), 110.5\left(\mathrm{C}_{17 \mathrm{~B}}\right), 110.3\left(\mathrm{C}_{17 \mathrm{~A}}\right), 73.9\left(\mathrm{C}_{13 \mathrm{~A}}\right), 73.8\left(\mathrm{C}_{13 \mathrm{~B}}\right)$, $29.3\left(\mathrm{C}_{15 \mathrm{~B}}\right), 29.3\left(\mathrm{C}_{15 \mathrm{~A}}\right), 9.0\left(\mathrm{C}_{24 \mathrm{~A}}\right), 9.0\left(\mathrm{C}_{24 \mathrm{~B}}\right) .{ }^{15} \mathrm{~N}$ NMR, projection from HMBC experiment, $\left(600 \mathrm{MHz}\right.$, acetone- $\left.\mathrm{d}_{6}\right) \delta=$ $298.7\left(\mathrm{~N}_{4-8}\right)$. ESI-MS (MeOH): $m / z=324.1,347.1(\mathrm{M}+\mathrm{Na})$. Elemental analysis, calcd. $(\%)$ for $\left(\mathrm{C}_{18} \mathrm{H}_{23} \mathrm{~N}_{4} \mathrm{O}_{3.5}\right): \mathrm{C}, 61.52 ; \mathrm{H}$, 6.59; N, 15.94; found: C, 61.78; H, 6.36; N, 15.80. The NMR labels are keyed in Figure 1.

$\left[\mathbf{R u}{ }^{\text {II }} \mathbf{C l}(\mathbf{H p b l})(\operatorname{trpy})\right]\left(\mathbf{P F}_{6}\right) \cdot \mathbf{C}_{3} \mathbf{H}_{\mathbf{6}} \mathbf{O} \cdot \mathbf{0 . 5} \mathbf{H}_{2} \mathbf{O}, \mathbf{1}\left(\mathbf{P F}_{6}\right) \mathbf{C}_{3} \mathbf{H}_{\mathbf{6}} \mathbf{O} \cdot \mathbf{0 . 5} \mathbf{H}_{2} \mathbf{O}$. A sample of $400 \mathrm{mg}(0.908 \mathrm{mmol})$ of $\left[\mathrm{RuCl}_{3}(\operatorname{trpy})\right]$ and 77 $\mathrm{mg}(1.816 \mathrm{mmol})$ of $\mathrm{LiCl}$ were dissolved in $40 \mathrm{~mL}$ of dry $\mathrm{MeOH}$ containing $250 \mu \mathrm{L}(1.816 \mathrm{mmol})$ of NEt $\mathrm{N}_{3}$. The mixture was stirred at room temperature (RT) for 20 minutes and then $294 \mathrm{mg}(0.908 \mathrm{mmol})$ of $\mathrm{Hpbl}$ were added. The resulting solution was stirred at $40{ }^{\circ} \mathrm{C}$ overnight. After that, the mixture was filtered and $2 \mathrm{~mL}$ of a saturated aqueous $\mathrm{NH}_{4} \mathrm{PF}_{6}$ solution and $5 \mathrm{~mL}$ of water were added. The volume of the resulting solution was reduced on a rotary evaporator until a precipitate appeared. After one day at $5{ }^{\circ} \mathrm{C}$ the precipitate was filtered off. The solid was extracted with $\mathrm{CH}_{2} \mathrm{Cl}_{2}$ until the organic solvent was colorless and the insoluble material was filtered off and discarded. The resulting solution was purified by column chromatography using neutral alumina as solid phase. The first three fractions eluted with a $\mathrm{CH}_{2} \mathrm{Cl}_{2}: \mathrm{MeOH}(140: 1)$ mixture were discarded. The desired product was finally eluted with pure $\mathrm{MeOH}$. This fraction was reduced to dryness and the brown powder obtained was dissolved in acetone and again $1 \mathrm{~mL}$ of a saturated aqueous $\mathrm{NH}_{4} \mathrm{PF}_{6}$ solution and $3 \mathrm{~mL}$ of water were added. The volume was then reduced on a rotary evaporator until a solid came out. The mixture was then cooled down in the fridge for $12 \mathrm{~h}$ and the solid obtained was filtered off, washed with cold water $(3 \times 5 \mathrm{~mL})$ and diethyl ether $(3 \times 5 \mathrm{~mL})$ and vacuum dried. The isolated product maintains the 3.0:1.7 diasteriomeric mixture of the starting Hpbl ligand. Yield: $311 \mathrm{mg}$ (41\%). Elemental analysis, calcd. (\%) for $\mathrm{C}_{36} \mathrm{H}_{38} \mathrm{ClF}_{6} \mathrm{~N}_{7} \mathrm{O}_{3.5} \mathrm{PRu}: \mathrm{C}, 47.71 ; \mathrm{H}, 4.23 ; \mathrm{N}$,

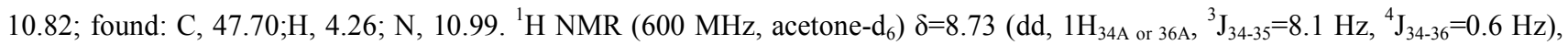

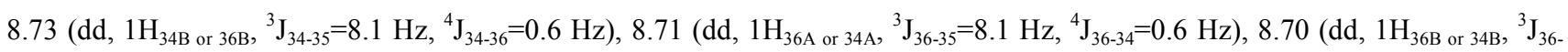


$\left.{ }_{35}=8.1 \mathrm{~Hz},{ }^{4} \mathrm{~J}_{36-34}=0.6 \mathrm{~Hz}\right), 8.64-8.60\left(\mathrm{~m}, 3 \mathrm{H}_{29-40-9 \mathrm{~A}, \mathrm{~B}}\right), 8.39\left(\mathrm{dd}, 1 \mathrm{H}_{43 \mathrm{~A} \text { or } 32 \mathrm{~A},}{ }^{3} \mathrm{~J}_{43-42}=5.4 \mathrm{~Hz},{ }^{4} \mathrm{~J}_{43-41}=1.6 \mathrm{~Hz},{ }^{5} \mathrm{~J}_{43-40}=0.6 \mathrm{~Hz}\right), 8.35(\mathrm{dd}$,

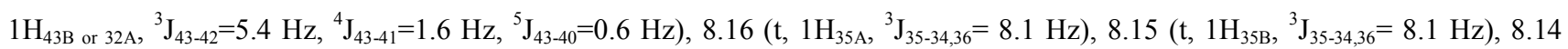

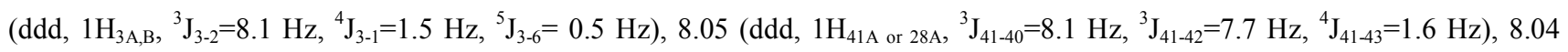

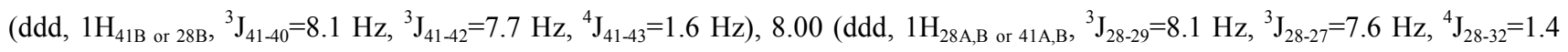
$\mathrm{Hz}), 7.90\left(\mathrm{ddd}, 1 \mathrm{H}_{11 \mathrm{~B}},{ }^{3} \mathrm{~J}_{11-12}=8.1 \mathrm{~Hz},{ }^{2} \mathrm{~J}_{11-10}=7.6 \mathrm{~Hz},{ }^{3} \mathrm{~J}_{11-9}=1.8 \mathrm{~Hz}\right), 7.90\left(\mathrm{ddd}, 1 \mathrm{H}_{11 \mathrm{~A}},{ }^{3} \mathrm{~J}_{11-12}=8.1 \mathrm{~Hz},{ }^{2} \mathrm{~J}_{11-10}=7.6 \mathrm{~Hz},{ }^{3} \mathrm{~J}_{11-9}=1.8 \mathrm{~Hz}\right.$ ), $7.89\left(\mathrm{~d}, 1 \mathrm{H}_{32 \mathrm{~A}, \mathrm{~B} \text { or } 43 \mathrm{~A}, \mathrm{~B}}\right.$, under another signal), $7.79\left(\mathrm{ddd}, 1 \mathrm{H}_{12 \mathrm{~A}},{ }^{3} \mathrm{~J}_{12-11}=8.1 \mathrm{~Hz},{ }^{4} \mathrm{~J}_{12-10}=1.0 \mathrm{~Hz},{ }^{5} \mathrm{~J}_{12-9}=0.9 \mathrm{~Hz}\right), 7.77\left(\mathrm{ddd}, 1 \mathrm{H}_{12 \mathrm{~B}},{ }^{3} \mathrm{~J}_{12}\right.$.

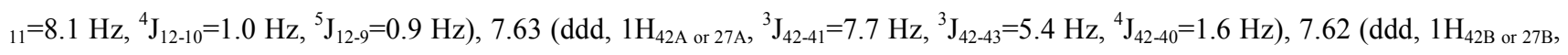
$\left.{ }^{3} \mathrm{~J}_{42-41}=7.7 \mathrm{~Hz},{ }^{3} \mathrm{~J}_{42-43}=5.4 \mathrm{~Hz},{ }^{4} \mathrm{~J}_{42-40}=1.6 \mathrm{~Hz}\right), 7.61\left(\mathrm{ddd} 1 \mathrm{H}_{2 \mathrm{~A}, \mathrm{~B}},{ }^{3} \mathrm{~J}_{2-3}=8.1 \mathrm{~Hz},{ }^{3} \mathrm{~J}_{2-1}=7.2 \mathrm{~Hz},{ }^{4} \mathrm{~J}_{2-6}=1.6 \mathrm{~Hz}\right), 7.47\left(\mathrm{ddd}, 1 \mathrm{H}_{6 \mathrm{~A}},{ }^{3} \mathrm{~J}_{6-1}=6.1\right.$

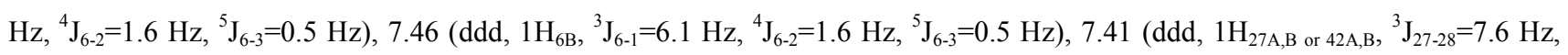
$\left.{ }^{3} \mathrm{~J}_{27-32}=5.7 \mathrm{~Hz},{ }^{4} \mathrm{~J}_{27-32}=1.5 \mathrm{~Hz}\right), 7.36\left(\mathrm{ddd}, 1 \mathrm{H}_{10 \mathrm{~A}, \mathrm{~B}},{ }^{3} \mathrm{~J}_{10-11}=7.6 \mathrm{~Hz},{ }^{3} \mathrm{~J}_{10-9}=4.8 \mathrm{~Hz},{ }^{4} \mathrm{~J}_{10-12}=1.0 \mathrm{~Hz}\right), 6.75\left(\mathrm{ddd}, 1 \mathrm{H}_{1 \mathrm{~A}},{ }^{3} \mathrm{~J}_{1-2}=7.2 \mathrm{~Hz},{ }^{3} \mathrm{~J}_{1-}\right.$ $\left.{ }_{6}=6.1 \mathrm{~Hz},{ }^{4} \mathrm{~J}_{1-3}=1.5 \mathrm{~Hz}\right), 6.75\left(\mathrm{ddd}, 1 \mathrm{H}_{1 \mathrm{~A}},{ }^{3} \mathrm{~J}_{1-2}=7.2 \mathrm{~Hz},{ }^{3} \mathrm{~J}_{1-6}=6.1 \mathrm{~Hz},{ }^{4} \mathrm{~J}_{1-3}=1.5 \mathrm{~Hz}\right), 5.99\left(\mathrm{~s}, 1 \mathrm{H}_{14 \text { or } 22 \mathrm{~A}, \mathrm{~B}}\right), 5.91\left(\mathrm{~s}, 1 \mathrm{H}_{14}\right.$ or $\left.22 \mathrm{~A}, \mathrm{~B}\right), 2.48(\mathrm{~s}$, $\left.3 \mathrm{H}_{24 \mathrm{~B}}\right), 2.41\left(\mathrm{~s}, 3 \mathrm{H}_{24 \mathrm{~A}}\right), 1.71\left(\mathrm{~s}, 3 \mathrm{H}_{15 \mathrm{~B}}\right), 1.71\left(\mathrm{~s}, 3 \mathrm{H}_{15 \mathrm{~A}}\right) \cdot{ }^{13} \mathrm{C}\left\{{ }^{1} \mathrm{H}\right\}$ NMR $\left(100 \mathrm{MHz}\right.$, acetone- $\left.\mathrm{d}_{6}\right) \delta=171.3\left(\mathrm{C}_{5 \mathrm{~A}, \mathrm{~B}}\right), 164.3\left(\mathrm{C}_{7 \mathrm{~A}}\right), 164.2$ $\left(\mathrm{C}_{7 \mathrm{~B}}\right), 161.2\left(\mathrm{C}_{33 \mathrm{~A}, \mathrm{~B}}\right.$ or $\left.\mathrm{C}_{37 \mathrm{~A}, \mathrm{~B}}\right), 161.1\left(\mathrm{C}_{37 \mathrm{~A}, \mathrm{~B}}\right.$ or $\left.\mathrm{C}_{33 \mathrm{~A}, \mathrm{~B}}\right), 160.8\left(\mathrm{C}_{39 \mathrm{~A}}\right.$ or. $\left.\mathrm{C}_{30 \mathrm{~B}}\right), 160.8\left(\mathrm{C}_{39 \mathrm{~A}}\right.$ or. $\left.\mathrm{C}_{30 \mathrm{~A}}\right), 160.5\left(\mathrm{C}_{30 \mathrm{~B}}\right.$ or $\left.\mathrm{C}_{39 \mathrm{~B}}\right), 160.5\left(\mathrm{C}_{30 \mathrm{~A}}\right.$ or $\left.\mathrm{C}_{39 \mathrm{~A}}\right), 154.6\left(\mathrm{C}_{43 \mathrm{~A}, \mathrm{~B}}\right.$ or $\left.\mathrm{C}_{32 \mathrm{~A}, \mathrm{~B}}\right), 153.88\left(\mathrm{C}_{6 \mathrm{~A}}\right), 153.84\left(\mathrm{C}_{6 \mathrm{~B}}\right), 153.0\left(\mathrm{C}_{32 \mathrm{~A}}\right.$ or $\left.\mathrm{C}_{43 \mathrm{~A}}\right), 153.0\left(\mathrm{C}_{32 \mathrm{~B}}\right.$ or $\left.\mathrm{C}_{43 \mathrm{~B}}\right), 152.8\left(\mathrm{C}_{16 \mathrm{~A}, \mathrm{~B}}\right), 149.2\left(\mathrm{C}_{29 \mathrm{~A}, \mathrm{~B}}\right.$ or $\left.\mathrm{C}_{40 \mathrm{~A}, \mathrm{~B}}\right), 148.9\left(\mathrm{C}_{20 \mathrm{~A}, \mathrm{~B}}\right), 138.2\left(\mathrm{C}_{11 \mathrm{~A}, \mathrm{~B}}\right), 137.8\left(\mathrm{C}_{41 \mathrm{~A}}\right.$ or $\left.\mathrm{C}_{28 \mathrm{~A}}\right), 137.8\left(\mathrm{C}_{41 \mathrm{~B}}\right.$ or $\left.\mathrm{C}_{28 \mathrm{~B}}\right), 137.77\left(\mathrm{C}_{28 \mathrm{~A}}\right.$ or $\left.\mathrm{C}_{41 \mathrm{~A}}\right), 137.75\left(\mathrm{C}_{28 \mathrm{~B}}\right.$ or $\left.\mathrm{C}_{41 \mathrm{~B}}\right), 137.56$ $\left(\mathrm{C}_{2 \mathrm{~A}}\right), 137.54\left(\mathrm{C}_{2 \mathrm{~B}}\right), 134.37\left(\mathrm{C}_{35 \mathrm{~A}}\right), 134.33\left(\mathrm{C}_{35 \mathrm{~B}}\right), 128.18\left(\mathrm{C}_{42 \mathrm{~A}}\right.$ or $\left.\mathrm{C}_{27 \mathrm{~A}}\right), 128.16\left(\mathrm{C}_{42 \mathrm{~B}}\right.$ or $\left.\mathrm{C}_{27 \mathrm{~B}}\right), 128.06\left(\mathrm{C}_{27 \mathrm{~A}}\right.$ or $\left.\mathrm{C}_{42 \mathrm{~A}}\right), 128.04\left(\mathrm{C}_{27 \mathrm{~B}}\right.$ or $\left.\mathrm{C}_{42 \mathrm{~B}}\right), 125.21\left(\mathrm{C}_{3 \mathrm{~B}}\right), 125.15\left(\mathrm{C}_{3 \mathrm{~A}}\right), 124.6\left(\mathrm{C}_{43 \mathrm{~A} A \mathrm{~B}}\right.$ or $\left.\mathrm{C}_{32 \mathrm{~A}, \mathrm{~B}}\right), 124.5\left(\mathrm{C}_{1 \mathrm{~A}, \mathrm{~B}}\right), 124.4\left(\mathrm{C}_{9 \mathrm{~A}}\right), 124.3\left(\mathrm{C}_{9 \mathrm{~B}}\right), 123.74\left(\mathrm{C}_{34 \mathrm{~A}, \mathrm{~B}}\right.$ or $\left.\mathrm{C}_{36 \mathrm{~A}, \mathrm{~B}}\right), 123.70$ $\left(\mathrm{C}_{10 \mathrm{~B}}\right), 123.66\left(\mathrm{C}_{10 \mathrm{~A}}\right), 123.25\left(\mathrm{C}_{36 \mathrm{~A}}\right.$ or $\left.\mathrm{C}_{34 \mathrm{~A}}\right), 123.22\left(\mathrm{C}_{36 \mathrm{~B}}\right.$ or $\left.\mathrm{C}_{34 \mathrm{~B}}\right), 121.09\left(\mathrm{C}_{12 \mathrm{~B}}\right), 121.04\left(\mathrm{C}_{12 \mathrm{~A}}\right), 114.1\left(\mathrm{C}_{17 \mathrm{~A}}\right), 113.8\left(\mathrm{C}_{17 \mathrm{~B}}\right), 76.86$ $\left(\mathrm{C}_{13}\right.$ or $\left.\mathrm{C}_{21 \mathrm{~A}}\right), 76.76\left(\mathrm{C}_{13}\right.$ or $\left.\mathrm{C}_{21 \mathrm{~B}}\right), 36.44\left(\mathrm{C}_{15 \mathrm{~A}}\right), 36.38\left(\mathrm{C}_{1 \mathrm{BB}}\right), 10.73\left(\mathrm{C}_{24 \mathrm{~B}}\right), 10.68\left(\mathrm{C}_{24 \mathrm{~A}}\right) .{ }^{15} \mathrm{~N}$ NMR, projection from HMBC experiment, $\left(600 \mathrm{MHz}\right.$, acetone- $\left.\mathrm{d}_{6}\right) \delta=199.6\left(\mathrm{~N}_{19},{ }^{1} \mathrm{~J}_{\mathrm{N}-\mathrm{H}}=108.2 \mathrm{~Hz}\right), 219.1\left(\mathrm{~N}_{18}\right), 228.9\left(\mathrm{~N}_{4}\right), 249.3\left(\mathrm{~N}_{44}\right.$ or $\left.\mathrm{N}_{31}\right), 252.6\left(\mathrm{~N}_{31}\right.$ or $\left.\mathrm{N}_{44}\right), 292.2$ $\left(\mathrm{N}_{38}\right), 305.2\left(\mathrm{~N}_{8}\right)$. ESI-MS $(\mathrm{MeOH}): m / z=694.1\left(\left[\mathrm{M}^{-\mathrm{PF}_{6}}\right]^{+}\right)$. UV-vis $\left(\mathrm{CH}_{2} \mathrm{Cl}_{2}\right)\left[\lambda_{\max }, \mathrm{nm}\left(\varepsilon, \mathrm{M}^{-1} \mathrm{~cm}^{-1}\right)\right]: 274(5217), 317(1523), 390$ (1335), 487 (1278), 519 (1127), 615 (377). CV (DCM/TBAH) $E_{1 / 2}=0.86 \mathrm{~V}$. NMR labels for complexes $\mathbf{1}^{+}$and $\mathbf{2}^{2+}$ are keyed in Figure 2 and 3.

$\left[\mathbf{R u} \mathbf{u}^{\mathrm{II}}(\mathbf{H p b l})(\mathbf{t r p y})\left(\mathbf{H}_{\mathbf{2}} \mathbf{O}\right)\right]^{\mathbf{2}^{+}}, \mathbf{2}^{\mathbf{2 +}}$. This complex was quantitatively generated in situ by dissolving $8.4 \mathrm{mg}(1 \mathrm{mmol})$ of complex $1\left(\mathrm{PF}_{6}\right)$ into $10 \mathrm{~mL}$ of $0.1 \mathrm{M}$ triflic acid aqueous solution $(\mathrm{pH}=1) .{ }^{1} \mathrm{H}$ NMR $\left(400 \mathrm{MHz}\right.$, acetone- $\left.\mathrm{d}_{6} / \mathrm{D}_{2} \mathrm{O} / \mathrm{CF}_{3} \mathrm{SO}_{3} \mathrm{D}\right) \delta=8.93(\mathrm{~d}$, $\left.1 \mathrm{H}_{9 \mathrm{~A}, \mathrm{~B}},{ }^{3} \mathrm{~J}_{9-10}=5.8 \mathrm{~Hz}\right), 8.77\left(\mathrm{td}, 1 \mathrm{H}_{11 \mathrm{~B}},{ }^{3} \mathrm{~J}_{11-10,12}=8.1 \mathrm{~Hz},{ }^{4} \mathrm{~J}_{11-9}=1.6 \mathrm{~Hz}\right), 8.76\left(\mathrm{td}, 1 \mathrm{H}_{11 \mathrm{~A}},{ }^{3} \mathrm{~J}_{11-10,12}=8.1 \mathrm{~Hz},{ }^{4} \mathrm{~J}_{11-9}=1.6 \mathrm{~Hz}\right), 8.66$

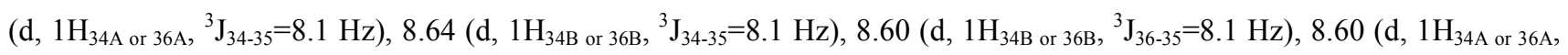

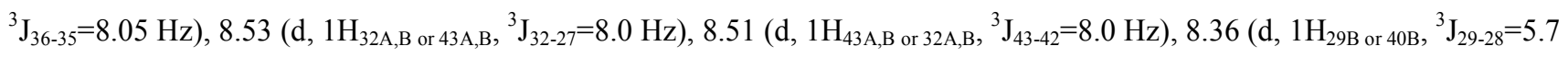

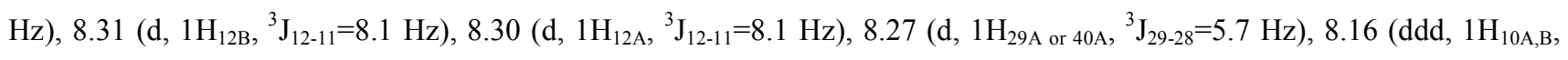
$\left.{ }^{3} \mathrm{~J}_{10-11}=8.1 \mathrm{~Hz},{ }^{3} \mathrm{~J}_{10-9}=5.8 \mathrm{~Hz},{ }^{4} \mathrm{~J}_{10-12}=1.1 \mathrm{~Hz}\right), 8.12\left(\mathrm{t}, 1 \mathrm{H}_{35 \mathrm{~A}},{ }^{3} \mathrm{~J}_{35-34,36}=8.1 \mathrm{~Hz}\right), 8.12\left(\mathrm{t}, 1 \mathrm{H}_{35 \mathrm{~B}},{ }^{3} \mathrm{~J}_{35-34,36}=8.1 \mathrm{~Hz}\right), 8.09$ (dd,

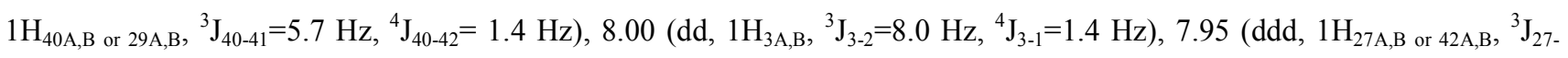

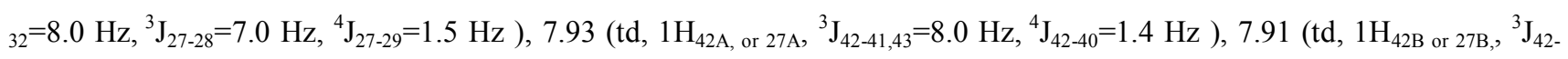

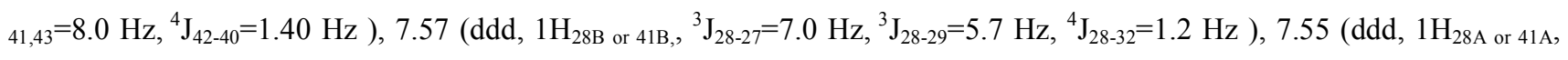
${ }^{3} \mathrm{~J}_{28-27}=7.0 \mathrm{~Hz},{ }^{3} \mathrm{~J}_{28-29}=5.7 \mathrm{~Hz},{ }^{4} \mathrm{~J}_{28-32}=1.2 \mathrm{~Hz}$ ), $7.53\left(\mathrm{ddd}, 1 \mathrm{H}_{2 \mathrm{~A}, \mathrm{~B}},{ }^{3} \mathrm{~J}_{2-3}=8.0 \mathrm{~Hz},{ }^{3} \mathrm{~J}_{2-1}=7.4 \mathrm{~Hz},{ }^{4} \mathrm{~J}_{2-6}=1.5 \mathrm{~Hz}\right.$ ), $7.38\left(\mathrm{ddd}, 1 \mathrm{H}_{41 \mathrm{~A} \text { or }}\right.$

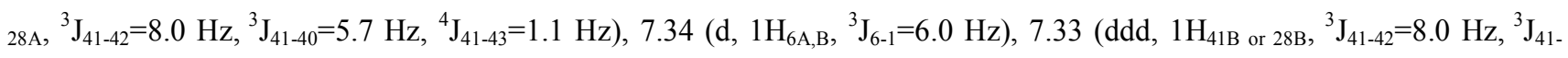
$\left.{ }_{40}=5.7 \mathrm{~Hz},{ }^{4} \mathrm{~J}_{41-43}=1.1 \mathrm{~Hz}\right), 6.66\left(\mathrm{ddd}, 1 \mathrm{H}_{1 \mathrm{~A}, \mathrm{~B}},{ }^{3} \mathrm{~J}_{1-2}=7.4 \mathrm{~Hz},{ }^{3} \mathrm{~J}_{1-6}=6.0 \mathrm{~Hz},{ }^{4} \mathrm{~J}_{1-3}=1.4 \mathrm{~Hz}\right), 2.28\left(\mathrm{~s}, 3 \mathrm{H}_{24 \mathrm{~B}}\right), 2.21\left(\mathrm{~s}, 3 \mathrm{H}_{24 \mathrm{~A}}\right), 2.21$ (s, $\left.3 \mathrm{H}_{15 \mathrm{~B}}\right), 2.20\left(\mathrm{~s}, 3 \mathrm{H}_{15 \mathrm{~A}}\right), 1.59\left(\mathrm{~s}, 3 \mathrm{H}_{23 \mathrm{~B}}\right), 1.56\left(\mathrm{~s}, 3 \mathrm{H}_{23 \mathrm{~A}}\right) \cdot{ }^{13} \mathrm{C}\left\{{ }^{1} \mathrm{H}\right\} \mathrm{NMR}\left(100 \mathrm{MHz}\right.$, acetone- $\left.\mathrm{d}_{6} / \mathrm{D}_{2} \mathrm{O} / \mathrm{CF}_{3} \mathrm{SO} \mathrm{O}_{3} \mathrm{D}\right) \delta=170.64$ $\left(\mathrm{C}_{5 \mathrm{~B}}\right), 170.59\left(\mathrm{C}_{5 \mathrm{~A}}\right), 160.6\left(\mathrm{C}_{33 \mathrm{~A}, \mathrm{~B}}\right.$ or $\left.\mathrm{C}_{37 \mathrm{~A}, \mathrm{~B}}\right), 160.5\left(\mathrm{C}_{33 \mathrm{~A}, \mathrm{~B}}\right.$ or $\left.\mathrm{C}_{37 \mathrm{~A}, \mathrm{~B}}\right), 160.2\left(\mathrm{C}_{30 \mathrm{~A}, \mathrm{~B}}\right), 159.7\left(\mathrm{C}_{30 \mathrm{~A}, \mathrm{~B}}\right), 157.9\left(\mathrm{C}_{7 \mathrm{~A}, \mathrm{~B}}\right), 154.7$ $\left(\mathrm{C}_{29 \mathrm{~A}, \mathrm{~B}}\right.$ or $\left.\mathrm{C}_{40 \mathrm{~A}, \mathrm{~B}}\right), 153.6\left(\mathrm{C}_{40 \mathrm{~B}}\right.$ or $\left.\mathrm{C}_{29 \mathrm{~B}}\right), 153.44\left(\mathrm{C}_{40 \mathrm{~A} \text { or } 29 \mathrm{~A}-6 \mathrm{~A}}\right), 153.40\left(\mathrm{C}_{6 \mathrm{~B}}\right), 148.80\left(\mathrm{C}_{11 \mathrm{~B}}\right), 148.75\left(\mathrm{C}_{11 \mathrm{~A}}\right), 144.2\left(\mathrm{C}_{16 \mathrm{~A}, \mathrm{~B}}\right)$, $142.332\left(\mathrm{C}_{9 \mathrm{~A}}\right), 142.29\left(\mathrm{C}_{9 \mathrm{~B}}\right), 137.97\left(\mathrm{C}_{42 \mathrm{~B}}\right.$ or $\left.\mathrm{C}_{27 \mathrm{~B}}\right), 137.95\left(\mathrm{C}_{42 \mathrm{~A}}\right.$ or $\left.\mathrm{C}_{27 \mathrm{~A}}\right), 137.88\left(\mathrm{C}_{27 \mathrm{~B}}\right.$ or $\left.\mathrm{C}_{42 \mathrm{~B}}\right), 137.82\left(\mathrm{C}_{27 \mathrm{~A}}\right.$ or $\left.\mathrm{C}_{42 \mathrm{~A}}\right)$, $137.56\left(\mathrm{C}_{2 \mathrm{~A}}\right), 137.53\left(\mathrm{C}_{2 \mathrm{~B}}\right), 135.0\left(\mathrm{C}_{35 \mathrm{~A}, \mathrm{~B}}\right), 128.2\left(\mathrm{C}_{20 \mathrm{~A}, \mathrm{~B}}\right), 128.2\left(\mathrm{C}_{41 \mathrm{~A}}\right.$ or $\left.\mathrm{C}_{28 \mathrm{~A}}\right), 128.2\left(\mathrm{C}_{41 \mathrm{~B}}\right.$ or $\left.\mathrm{C}_{28 \mathrm{~B}}\right), 128.0\left(\mathrm{C}_{28 \mathrm{~A}, \mathrm{~B}}\right.$ or $\left.\mathrm{C}_{41 \mathrm{~A}, \mathrm{~B}}\right)$, 


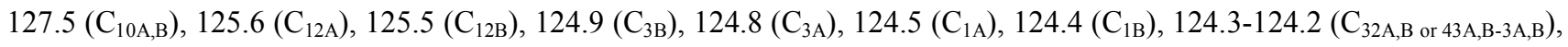
$123.7\left(\mathrm{C}_{34 \mathrm{~B}}\right.$ or $\left.\mathrm{C}_{36 \mathrm{~B}}\right), 123.6\left(\mathrm{C}_{34 \mathrm{~A}}\right.$ or $\left.\mathrm{C}_{36 \mathrm{~A}}\right), 123.1\left(\mathrm{C}_{34 \mathrm{~A}, \mathrm{~B}}\right.$ or $\left.\mathrm{C}_{36 \mathrm{~A}, \mathrm{~B}}\right), 115.5\left(\mathrm{C}_{17 \mathrm{~A}}\right), 115.3\left(\mathrm{C}_{17 \mathrm{~B}}\right), 76.3\left(\mathrm{C}_{13 \mathrm{~B}}\right.$ or $\left.\mathrm{C}_{21 \mathrm{~B}}\right), 76.2\left(\mathrm{C}_{13 \mathrm{~A}}\right.$ or $\left.\mathrm{C}_{21 \mathrm{~A}}\right), 71.5\left(\mathrm{C}_{13 \mathrm{~B}}\right.$ or $\left.\mathrm{C}_{21 \mathrm{~B}}\right), 71.3\left(\mathrm{C}_{13 \mathrm{~A}}\right.$ or $\left.\mathrm{C}_{21 \mathrm{~A}}\right), 36.0\left(\mathrm{C}_{23 \mathrm{~B}}\right), 36.9\left(\mathrm{C}_{23 \mathrm{~A}}\right), 27.2\left(\mathrm{C}_{15 \mathrm{~B}}\right), 27.1\left(\mathrm{C}_{15 \mathrm{~A}}\right), 10.2\left(\mathrm{C}_{24 \mathrm{~B}}\right), 10.1\left(\mathrm{C}_{24 \mathrm{~A}}\right)$. ${ }^{15} \mathrm{~N}$ NMR, projection from HMBC experiment $\left(600 \mathrm{MHz}\right.$, acetone- $\left.\mathrm{d}_{6} / \mathrm{D}_{2} \mathrm{O} / \mathrm{CF}_{3} \mathrm{SO}_{3} \mathrm{D}\right) \delta=289.0\left(\mathrm{~N}_{38}\right), 250.4\left(\mathrm{~N}_{44}\right.$ or $\left.\mathrm{N}_{31}\right)$, $247.2\left(\mathrm{~N}_{44}\right.$ or $\left.\mathrm{N}_{31}\right), 225.9\left(\mathrm{~N}_{4}\right), 196.6\left(\mathrm{~N}_{8}\right)$. ESI-MS $(\mathrm{MeOH}): m / z=658.2\left(\left[\mathrm{M}-2 \mathrm{PF}_{6}^{-}-\mathrm{H}^{+}\right]^{+}\right)$. UV-vis $(\mathrm{pH}=1,0.1 \mathrm{M}$ triflic acid aqueous solution) $\left[\lambda_{\max }, \mathrm{nm}\left(\varepsilon, \mathrm{M}^{-1} \mathrm{~cm}^{-1}\right)\right]: 270$ (5504), 310 (5449), 360 (1461), 450 (1207), 480 (1170). CV (pH = 1.0 triflic acid aqueous solution) $E_{1 / 2}=0.72 \mathrm{~V}, E_{1 / 2}=0.93 \mathrm{~V}$.

Instrumentation and Measurements: UV-vis spectroscopy was performed with a HP8453 spectrometer using $1 \mathrm{~cm}$ quartz cells. ${ }^{1} \mathrm{H}$ NMR spectroscopy was performed on a Bruker DPX $360 \mathrm{MHz}, 400 \mathrm{MHz}$ and $600 \mathrm{MHz}$ in Universitat Autònoma de Barcelona magnetic resonance service (SeRMN-UAB). Samples were run in acetone- $\mathrm{d}_{6}$, acetonitrile- $\mathrm{d}_{3}, \mathrm{D}_{2} \mathrm{O}$ with $\mathrm{CF}_{3} \mathrm{SO}_{3} \mathrm{D}$ or with $\mathrm{NaOD}$ with internal references (residual protons and/or tetramethylsilane). Elemental analyses were performed using a Carlo Erba CHMS EA-1108 instrument provided by the Chemical Analysis Service at UAB. ESI-MS experiments were performed on a HP298s GC-MS system from the CAS-UAB. CV experiments were performed with a PAR283 potentiostat using a three-electrode cell. A glassy carbon disk (3 mm diameter) was used as working electrode, platinum wire was used as auxiliary electrode, and a saturated sodium calomel electrode (SSCE) was used as the reference electrode. For the solutions of complexes in organic solvents, $n$ - $\mathrm{Bu}_{4} \mathrm{NPF}_{6}$ was used as supporting electrolyte to yield a solution with $0.1 \mathrm{M}$ ionic strength. All $E_{1 / 2}$ values reported here were estimated from cyclic voltammetry as the average of the oxidative and reductive peak potentials $\left(E_{\mathrm{p}, \mathrm{a}}+E_{\mathrm{p}, \mathrm{c}}\right) / 2$ and are referred to the SSCE reference electrode. Species concentration was approximately $1 \mathrm{mM}$. For the construction of the Pourbaix diagram the following buffers were used: hydrogen phthalate/triflic acid up to $\mathrm{pH}=4$, hydrogen phthalate/sodium hydroxide for $\mathrm{pH}=5.0$, dihydrogenphosphate/sodium hydroxide for $\mathrm{pH}=6.0$, borax/triflic acid for $\mathrm{pH}=7.0$, hydrogen phosphate/sodium hydroxide for the $\mathrm{pH}$ range 8-9. Also $0.1 \mathrm{M}$ triflic acid was used for $\mathrm{pH}=1.0$.

X-ray Crystal Structure Determination. Crystals of complex $\left[\mathrm{Ru}^{\mathrm{II}}(\mathrm{OH})(\mathrm{pbl})(\mathrm{trpy})\right]$ were obtained by slow evaporation of a $2^{2+} \quad \mathrm{D}_{2} \mathrm{O} /$ Acetone- $\mathrm{d}_{6} / \mathrm{NaOD}$ mixture. The measured crystals were prepared under inert conditions immersed in perfluoropolyether as protecting oil for manipulation.

Data collection: Regarding the crystal structure of complex $[\mathrm{Ru}(\operatorname{trpy})(\mathrm{pbl})(\mathrm{OH})]$ was carried out at room temperature $(298(2) \mathrm{K})$ on a BRUKER SMART APEX CCD diffractometer using graphite-monochromated Mo-Ka radiation from an xRay Tube. Programs used: Data collection SMART, ${ }^{13}$ data reduction Bruker Saint $+{ }^{14}$ and absorption correction SADABS. ${ }^{15}$

Structure Solution and Refinement: The solution and refinement of crystal structure of complex $[\mathrm{Ru}(\mathrm{OH})(\mathrm{pbl})(\operatorname{trpy})]$ was achieved using the SHELTL ${ }^{16}$ program.

Computational Details. The density functional theory (DFT) calculations have been carried out with the hybrid B3PW91 density ruthenium functional, ${ }^{17}$ as implemented in the Gaussian 09 package. ${ }^{18}$ The atoms have been represented with the quasi-relativistic effective core pseudo-potentials of the Stuttgart group and the associated basis sets augmented with a polarization function $(\alpha=1.235){ }^{19}$ The remaining atoms (carbon, oxygen, nitrogen and hydrogen) have been represented with $6-31 \mathrm{G}(\mathrm{d}, \mathrm{p})$ basis sets. ${ }^{20}$ The B3PW91 geometry optimizations were performed without any symmetry constraints, and the nature of the extrema (local minima or transition states, TS) was checked by analytical frequency calculations. The energies given throughout the article are Gibbs free energies with the ZPE corrections (however, inclusion of the ZPE 
corrections does not significantly modify the results) and thermal corrections in gas phase. The solvent effect was introduced by the polarizable continuum model $(\mathrm{PCM}),{ }^{21}$ implemented by Tomasi and co-workers via single point calculations on the optimized gas-phase geometries using the M06 functional ${ }^{22}$ and the cc-pVTZ basis set for $\mathrm{C}, \mathrm{O}, \mathrm{N}$ and $\mathrm{H}^{23}$ The cavity is created via a series of overlapping spheres. On the other hand, for the aqueous solvation free energy of the protons released, we assumed the value of $262.5 \mathrm{kcal} \mathrm{mol}^{-1}$ from the literature. ${ }^{24}$

\section{Results and Discussion}

1. Synthesis. The synthetic strategy followed to prepare the new Hpbl ligand is depicted in Scheme 1. It involves the double nucleophilic attack of a pyridine lithiate to the two ketone carbonyl groups of the pyrazolyl derivative I (Scheme 1), ${ }^{11 a, b}$ generating two alcoholic chiral centers. Column chromatography of the reaction crude gave, in the last eluted fraction, the desired $\mathrm{Hpbl}$ ligand as a mixture of two diastereomers in a ratio of 3.0:1.7 as can be observed in the ${ }^{1} \mathrm{H}-\mathrm{NMR}$ displayed in Figure 1.

Scheme 1. Synthesis of the Hpbl ligand.

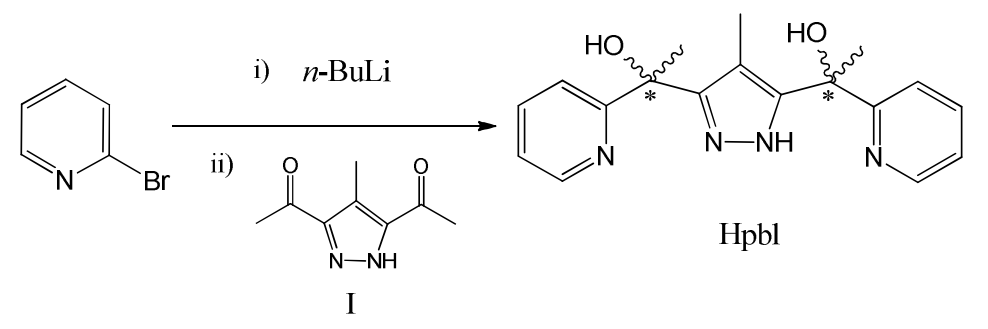

The mononuclear chlorido complex $\mathbf{1}^{+}$was obtained by the direct reaction of equimolar amounts of $\mathrm{Hpbl}$ and $\left[\mathrm{RuCl}_{3}(\operatorname{trpy})\right]$ in the presence of $\mathrm{NEt}_{3}$ at $40{ }^{\circ} \mathrm{C}$ as depicted in Scheme 2. Finally the aqua complex $\mathbf{2}^{2+}$, was quantitatively generated in situ when dissolving $\mathbf{1}^{+}$in acidic aqueous solutions. All the new compounds reported here were characterized by the usual analytic and spectroscopic techniques (see Supporting Information Figures S1-S16).

Scheme 2. Synthetic strategy used for the preparation of the complexes described in this work. $\mathrm{T}$ represents the trpy ligands where the axial $\mathrm{N}$-atoms are not shown for simplicity.

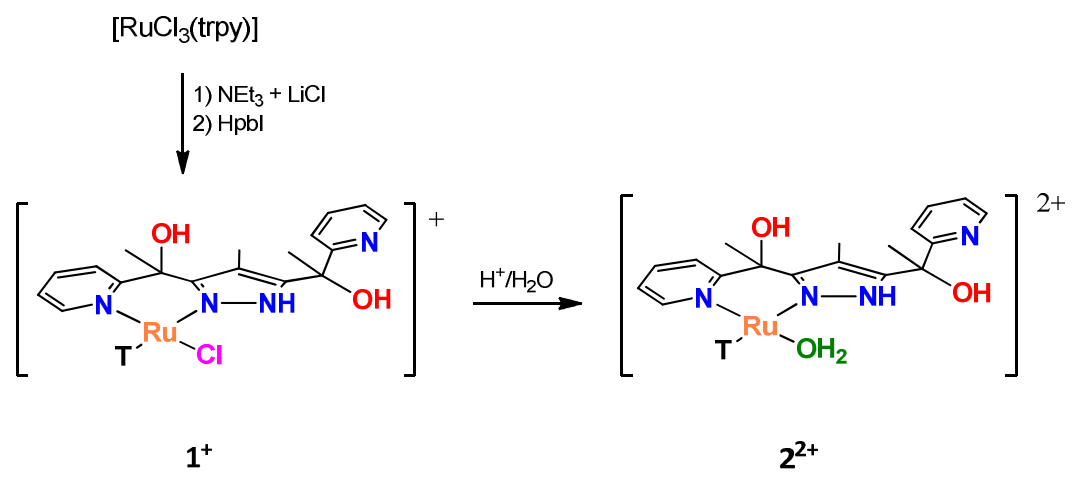


2. NMR and UV-vis Spectroscopy. 1D and 2D NMR spectroscopy was used to structurally characterize in solution the Hpbl ligand as well as complexes $\mathbf{1}^{+}$and $\mathbf{2}^{\mathbf{2 +}}$ (see Figure 1 and 2, the Experimental Section and Figures S1-S6 in the Supporting Information).

For the Hbpl ligand, all the resonances observed in the ${ }^{1} \mathrm{H}-\mathrm{NMR}$ spectra for the free ligand can be unambiguously assigned based on their integrals, symmetry and multiplicity. In solution, the Hbpl ligand presents either a $C_{2^{-}}$or a $\sigma$-symmetry axis, depending on the diastereoisomer, that bisects the pyrazolyl group and interconverts each side of the ligand, thus becoming magnetically equivalent as can be noted in Figure 1. In this Figure it can also be observed the 3.0:1.7 ratio of the two diastereoisomers appearing as a duplicate. Particularly interesting and useful is the HMBC-N NMR that shows the presence of all the Hbpl Nitrogen resonances at 298.7 ppm, strongly coupled to H2, H3 and the OH proton, as shown in Figure 3.

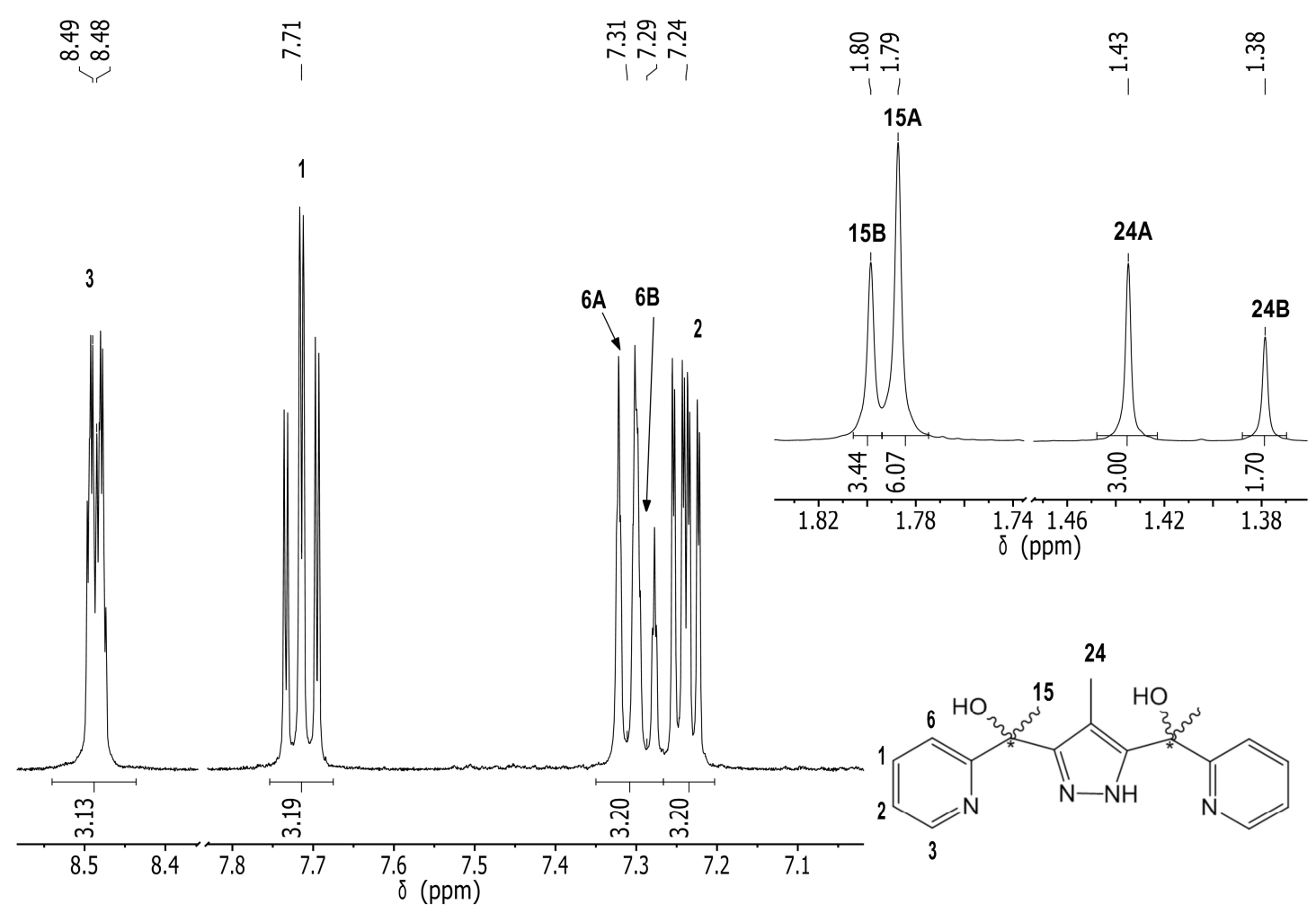

Figure 1. ${ }^{1} \mathrm{H}-\mathrm{NMR}$ spectrum of $\mathrm{Hpbl}$ in acetonitrile- $\mathrm{d}_{3}$. Bottom, aromatic region and numbering scheme. Top, aliphatic region where a 3.0:1.7 diasteriomeric mixture ratio can be clearly observed for the Me protons.

Complexes $\mathbf{1}^{+}$and $\mathbf{2}^{2+}$ have no symmetry elements due to the coordination of the Ru metal center in one the ligand sides and thus all the resonances are now magnetically different. For complex $\mathbf{1}^{+}$we managed to highly enrich one sample up to a 8.0:1.0 diastereomeric ratio by means of preparative TLC. A ${ }^{1} \mathrm{H}-\mathrm{NMR}$ spectrum of the latter with the assignment is shown in Figure 2 and additional 2D spectrum is depicted in the supporting information figure S3. There a number of features related to the NMR spectra that are worth mentioning and that are useful for the structural characterization of this complex. First, both alcohol protons can be observed at low and similar chemical shifts (5.99 and $5.91 \mathrm{ppm}$ ), which is indicative that they are not coordinated to the metal center. Second, the absence of resonances in the 9-10 ppm region is indicative of the in- 
isomer, ${ }^{26}$ where the $\mathrm{Ru}-\mathrm{Cl}$ bond is directed towards the center of the Hbpl ligand, meaning that the chlorido ligand is trans to the pyridyl ligand. On the other hand the out-isomer that would have the $\mathrm{Ru}-\mathrm{Cl}$ bond trans to the Ru-N pyrazolyl bond would be responsible for the deshielding of the $\mathrm{H} 3$ hydrogen towards the 9-10 ppm region. ${ }^{26}$

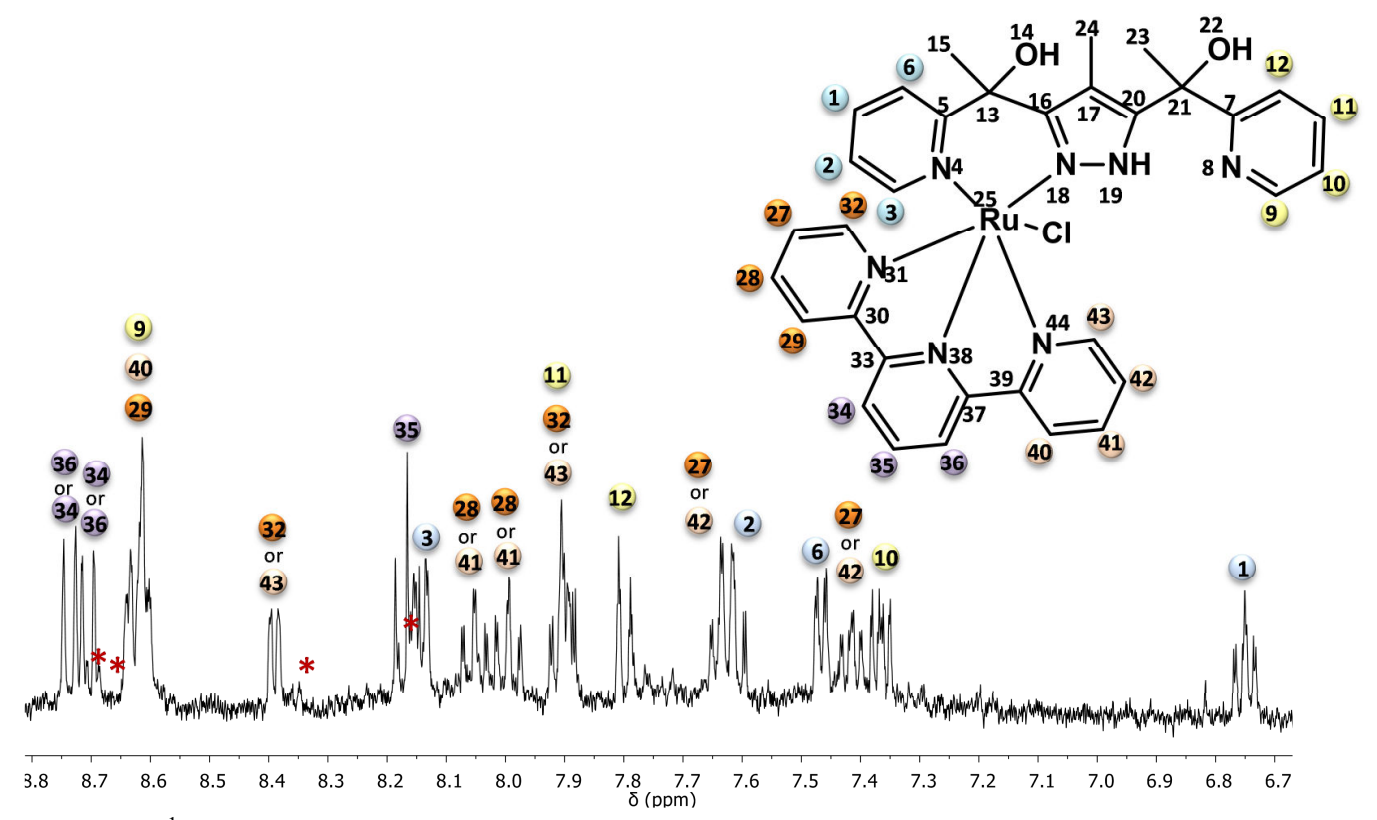

Figure 2. ${ }^{1} \mathrm{H}-\mathrm{NMR}$ spectrum of the aromatic region of a diastereomerically enriched mixture (8:1) of $\mathbf{1}^{+}$ and its corresponding drawing and numbering scheme. Orange and light orange trpy protons remain indistinguishable. The residual signals of low concentration diastereomer B are marked with a red asterisk.

Third, the HMBC-N NMR shown in Figure 3, is fully consistent with the previous assignment. The pyrazolyl N atoms appear at 200 and $215 \mathrm{ppm}$ for the coordinated to Ru and the protonated one respectively. The former appears as a doublet due to its coupling with the proton. The non-coordinated pyridyl Hbpl N8 atom appears at 305 ppm, very close to the ones of the free ligands while the coordinated N4 one is upfield shifted to $230 \mathrm{ppm}$. Finally the trpy N atoms appear very close at 249 and $251 \mathrm{ppm}$. It is interesting to see here that the HMBC-N NMR experiment is a very powerful tool for the diagnosis of coordinated vs. non-coordinated $\mathrm{N}$ atoms of a particular ligand, especially with multiple $\mathrm{N}$-coordinating sites. 


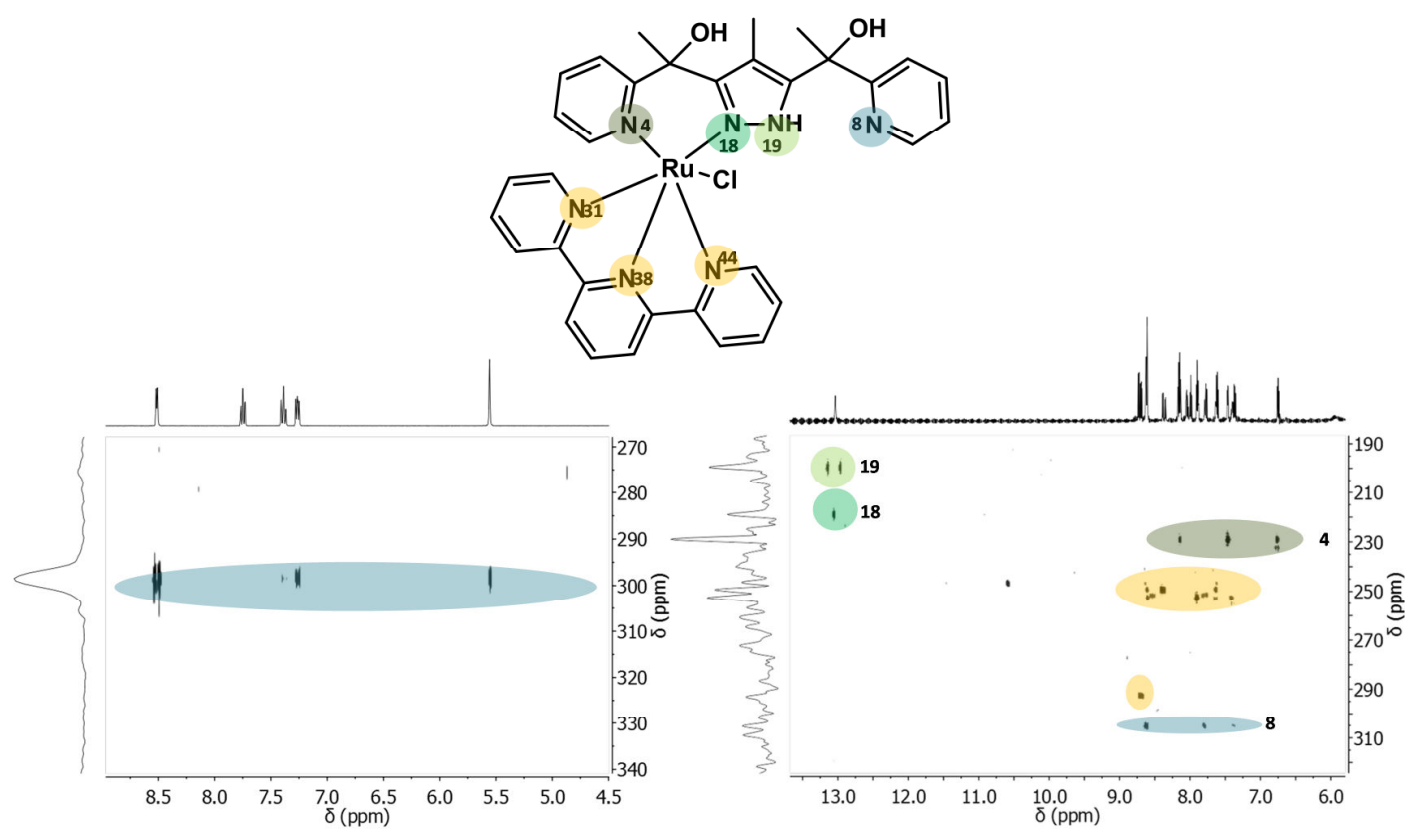

Figure 3. HMBC-N spectra for the Hbpl free ligand (left) and complex $\mathbf{1}^{+}$(right) in acetone- $\mathrm{d}_{6}$ together with a drawing and numbering scheme.

The NMR spectra for the aqua complex $\mathbf{2}^{2+}$ was recorded in acetone- $\mathrm{d}_{6}$ acidified with a drop of a $0.1 \mathrm{M}$ solution of $\mathrm{CF}_{3} \mathrm{SO}_{3} \mathrm{D}$ in $\mathrm{D}_{2} \mathrm{O}$. The main differences in the spectra with regard to the $\mathbf{1}^{+}$spectrum are the up field shift of the resonances belonging to non-coordinated pyridyl ligand that is protonated under these conditions. A spectacular effect is observed in the NMR when complex $2^{2+}$ is recorded in basic solution (acetone- $\mathrm{d}_{6}$ basified with a drop of $0.1 \mathrm{M} \mathrm{NaOD}$ in $\mathrm{D}_{2} \mathrm{O}$ ). Under these conditions a large amount of resonances appear which are indicative of new complexes being formed. DOSY experiments carried out under exactly the same conditions indicate that the new complexes formed are mononuclear in nature, since all of them have the same diffusion coefficients and similar to $\left[\mathrm{Ru}(\text { bpea })(\mathrm{bpy})\left(\mathrm{H}_{2} \mathrm{O}\right)\right]^{2+}$ (bpea is N,N-bis(pyridin-2-ylmethyl)ethanamine; bpy is $2,2^{\prime}$-bipyridine) used as reference ${ }^{25,28 a}$ (See supporting information, figure $\mathrm{S} 6$ ).

The UV-vis spectra in $\mathrm{CH}_{2} \mathrm{Cl}_{2}$ and $\mathrm{H}_{2} \mathrm{O} /$ trifluoroacetic acid for complexes $\mathbf{1}^{+}$and $\mathbf{2}^{\mathbf{2}}$, are displayed in Figure 4 and Figures S8-S9 in the supporting information. The observed absorptions agree with those reported for similar complexes. ${ }^{26}$ The spectra can be divided in three different regions: between 200 and $350 \mathrm{~nm}$, where very intense bands are observed due to intraligand $\pi$ - $\pi^{*}$ transitions ${ }^{27}$ between 350 and $560 \mathrm{~nm}$, in which there are mainly broad unsymmetrical $\mathrm{Ru}(\mathrm{d} \pi)$-trpy/Hpbl $\left(\pi^{*}\right)$ metal-to-ligand charge transfer (MLCT) bands; ${ }^{28}$ and finally the region above $560 \mathrm{~nm}$ in which d-d transitions are observed. ${ }^{29}$ Figure S8 (supporting information) shows the UV-vis spectra for complexes $\mathbf{1}^{+}$and $\mathbf{2}^{\mathbf{2 +}}$ where different band displacement for the broad overlapped $\mathrm{Ru}(\mathrm{d} \pi)$-trpy/Hpbl( $\left.\pi^{*}\right)$ MLCT bands is observed. The blue-shift exhibited by complex $\mathbf{2}^{2+}$ confirms the coordination of the aqua ligand that relatively stabilizes the $\mathrm{d} \pi(\mathrm{Ru})$ levels and therefore gives rise to more energetic electronic transitions. ${ }^{28}$

Generation of the higher oxidation state species of complex $\mathbf{2}^{2+}$ was followed spectrophotometrically. The spectra obtained upon progressive addition of small amounts of $\mathrm{Ce}(\mathrm{IV})$ to an aqueous solution of the complex at $\mathrm{pH}=1.0$ until the addition of 1 oxidant equivalent is shown in Figure 4. The three isosbestic points observed at $\lambda=294,386$, and $426 \mathrm{~nm}$ suggest the neat 
generation of the $\mathrm{Ru}(\mathrm{III})$ species. Addition of a second equivalent of $\mathrm{Ce}(\mathrm{IV})$ produces a further oxidation of the complex that generates the corresponding $\mathrm{Ru}(\mathrm{IV})$-oxo species, which is almost featureless in the visible region, as has been described for analogous complexes. ${ }^{30}$ This second redox process also takes place with the presence of isosbestic points at 294,386 and 426 $\mathrm{nm}$, and is shown in (See supporting information figure S9).

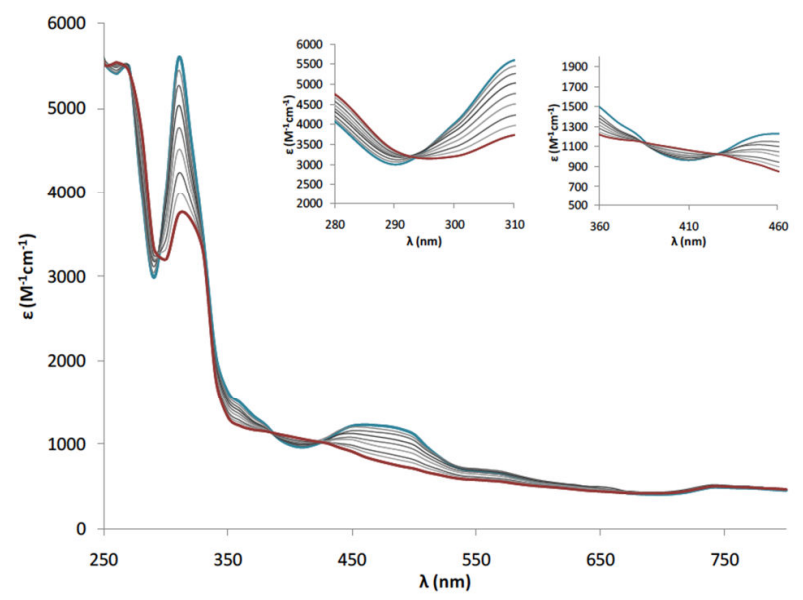

Figure 4. UV-vis spectrophotometric titration of complex $\mathbf{2}^{2+}$ with $\mathrm{Ce}(\mathrm{IV})$. A sample of $0.5 \mathrm{~mL}$ of $\mathbf{2}^{\mathbf{2 +}} 0.1 \mathrm{mM}$ was titrated with 8 sequential additions of $10 \mu \mathrm{L}$ of $0.6 \mathrm{mM} \mathrm{Ce}(\mathrm{IV})$. Both solutions in a $\mathrm{pH}=1.0$ trifluoroacetic acid aqueous solution. $\mathrm{Ru}(\mathrm{II})$ : blue line, $\mathrm{Ru}(\mathrm{III})$ : red line. Inset: zoom of the isosbestic points region.

3. Electrochemistry and Linkage Isomerism. The redox properties of complexes $\mathbf{1}^{+}$and $\mathbf{2}^{\mathbf{2 +}}$ have been studied by cyclic voltammetry (CV) using glassy carbon disk electrodes. A common feature to most Ru-aqua complexes is the fact that their redox waves are more diffuse than the ones for the $\mathrm{Ru}-\mathrm{Cl}$ complexes that are generally very well defined. In order to improve this we tried a variety of working electrodes including boron doped diamond electrodes, Pt ore even Au electrodes, but they did not yield any significant improvement.

Complex $\mathbf{1}^{+}$, dissolved in dichloromethane and using $0.1 \mathrm{Mn}-\mathrm{Bu}_{4} \mathrm{NPF}_{6}$ as supporting electrolyte, displays one electrochemically quasi-reversible redox wave (See supporting information Figure S10) at $E_{1 / 2}=0.840 \mathrm{~V}$, which is assigned to the formation of the corresponding Ru(III) complex,

\section{$\left[\mathrm{Ru}{ }^{\mathrm{II}} \mathrm{Cl}(\mathrm{Hpbl})(\operatorname{trpy})\right]^{+} \rightarrow \quad\left[\mathrm{Ru}^{\mathrm{III}} \mathrm{Cl}(\mathrm{Hpbl})(\operatorname{trpy})\right]^{2+}+1 \mathrm{e}^{-}(1)$<smiles>[3H][InH]</smiles>

Complex $\mathbf{2}^{2+}$ was generated in situ by dissolving $\mathbf{1}^{+}$in a $0.1 \mathrm{M}$ trifluoroacetic acid $(\mathrm{pH}=1.0)$ aqueous solution. At high scan rates $(1 \mathrm{~V} / \mathrm{s})$ the $\mathrm{CV}$ of $\mathbf{2}^{2+}$ presents two different redox processes (Figure 5a), the first and more intense one at $E_{1 / 2}=0.725 \mathrm{~V}$ that is associated to the first one electron oxidation (Wave A in Figure 5a),

$\left[\mathrm{Ru}^{\mathrm{II}}(\mathrm{Hpbl})(\operatorname{trpy})\left(\mathrm{H}_{2} \mathrm{O}\right)\right]^{2+}->\left[\mathrm{Ru}^{\mathrm{III}}\left(\mathrm{H}_{2} \mathrm{O}\right)(\mathrm{Hpbl})(\operatorname{trpy})\right]^{3+}+1 \mathrm{e}^{-}$

$2^{2+}$ $2^{3+}$ 
and the second and weaker one at $E_{1 / 2}=0.932 \mathrm{~V}$ corresponding to the III/IV oxidation step (Wave B in Figure 5a),

$$
\begin{array}{cc}
{\left[\mathrm{Ru}^{\mathrm{III}}\left(\mathrm{H}_{2} \mathrm{O}\right)(\mathrm{Hpbl})(\operatorname{trpy})\right]^{3+}->} & {\left[\mathrm{Ru}^{\mathrm{IV}}(\mathrm{OH})(\mathrm{Hpbl})(\operatorname{trpy})\right]^{3+}+1 \mathrm{e}^{-}+1 \mathrm{H}^{+}} \\
\mathbf{2}^{\mathbf{3}^{+}} & \mathbf{2}^{\mathbf{3}^{+}}
\end{array}
$$

At a scan rate of $0.1 \mathrm{~V} / \mathrm{s}$ and up to $1.5 \mathrm{~V}$ (Figure $5 \mathrm{~b}$ ) a large anodic current is observed (D in Figure 5b) that is associated with a further one electron oxidation of the complex to $\mathrm{Ru}(\mathrm{V})$ with concomitant electrocatalytic oxygen generation similarly proposed for other mononuclear Ru-aqua complexes ${ }^{9 \mathrm{a}}$

(a)

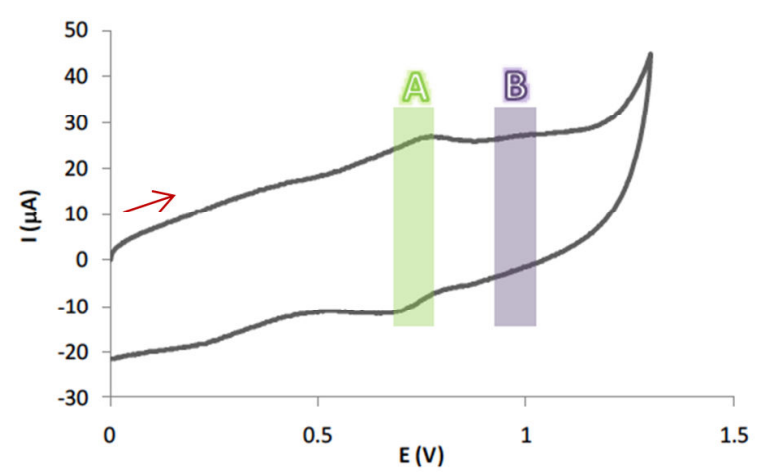

(b)

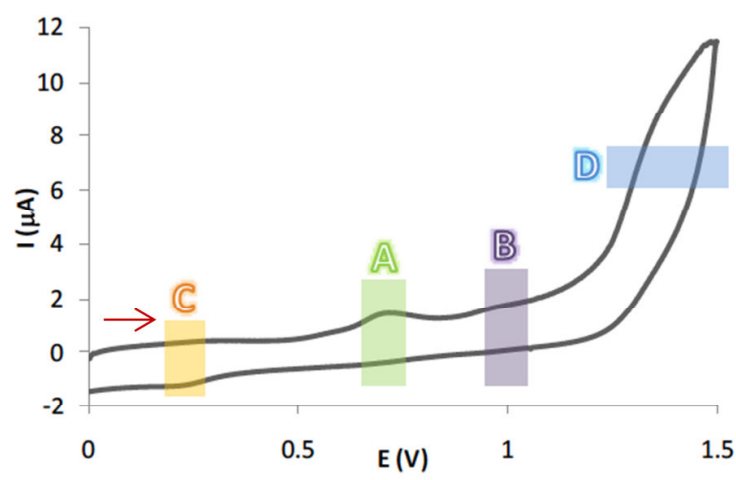

Figure 5. $\mathrm{CV}$ of complex $2^{2+}$ in a $\mathrm{pH}=1.0$ in a $0.1 \mathrm{M} \mathrm{CF}_{3} \mathrm{COOH}$ aqueous solution at: (a) $1 \mathrm{~V} / \mathrm{s}$ and (b) $20 \mathrm{mV} / \mathrm{s}$. The red arrow indicates the scanning direction

The presence of linkage isomerization is observed by CV when a solution of complex $\mathbf{2}^{2+}$ is scanned cathodically after holding an applied potential of $0.9 \mathrm{~V}$ for 3 minutes (see Figure 6 ) at different scan rates and observing the changes on $\left[i_{c 1}\right] /\left[i_{a 1}\right]$ and $\left[\mathrm{i}_{\mathrm{c} 2}\right] /\left[\mathrm{i}_{\mathrm{a} 2}\right]$ of the waves at 0.30 (Wave $\mathrm{A}$ in Figure 6) and $0.8 \mathrm{~V}$ (Wave $\mathrm{C}$ in Figure 6) respectively. The latter is the wave

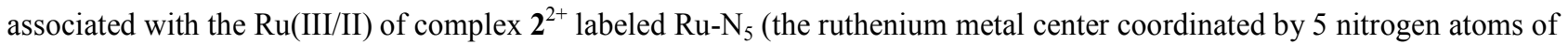
the ligands: three from the trpy and two from the $\mathrm{Hpbl}$ ) in Scheme 3, whereas the wave at $0.3 \mathrm{~V}$ is associated with the III/II couple for $\mathrm{Ru}-\mathrm{ON}_{4}(\mathrm{Pz})$ isomer (coordination to the ruthenium metal center by one hydroxyl oxygen and four nitrogen atoms: three from trpy and one from the pyrazolyl moiety of the Hpbl ligand; this isomer nomenclature is further described in Scheme 3 and Figure 9). It is proposed that when the oxidation state III for the $\mathrm{Ru}^{\mathrm{III}}-\mathrm{N}_{5}\left(2^{3+}\right)$ isomer is reached the oxygen from the alkoxy is coordinated with concomitant decoordination of the pyridyl group of the Hbpl ligand, generating a new isomer labeled $\mathrm{Ru}^{\mathrm{III}}-\mathrm{ON}_{4}(\mathrm{Pz})\left(2^{3+}\right)$. This hypothesis is further corroborated by the strong cathodic shift (roughly $500 \mathrm{mV}$ ) of the new couple due to strong sigma-donation capacity of the anionic alkoxy coordination and is in agreement with the HardSoft Acid-Base Pearson theory. ${ }^{3}$ Further evidence for this coordination environment comes from the isolation of low quality crystal of $\mathrm{Ru}^{\mathrm{II}}-\mathrm{ON}_{4}(\mathrm{Pz})\left(2^{3+}\right)$ (See supporting information table $\mathrm{S} 1$ and figure $\mathrm{S} 7$ ). Although distances and angles are not reliable for this structure the connectivity among atoms is fully trustable and coincides with the proposed structure for the $\mathrm{Ru}^{\mathrm{II}}-\mathrm{ON}_{4}(\mathrm{Pz})\left(2^{3+}\right)$ complex. 


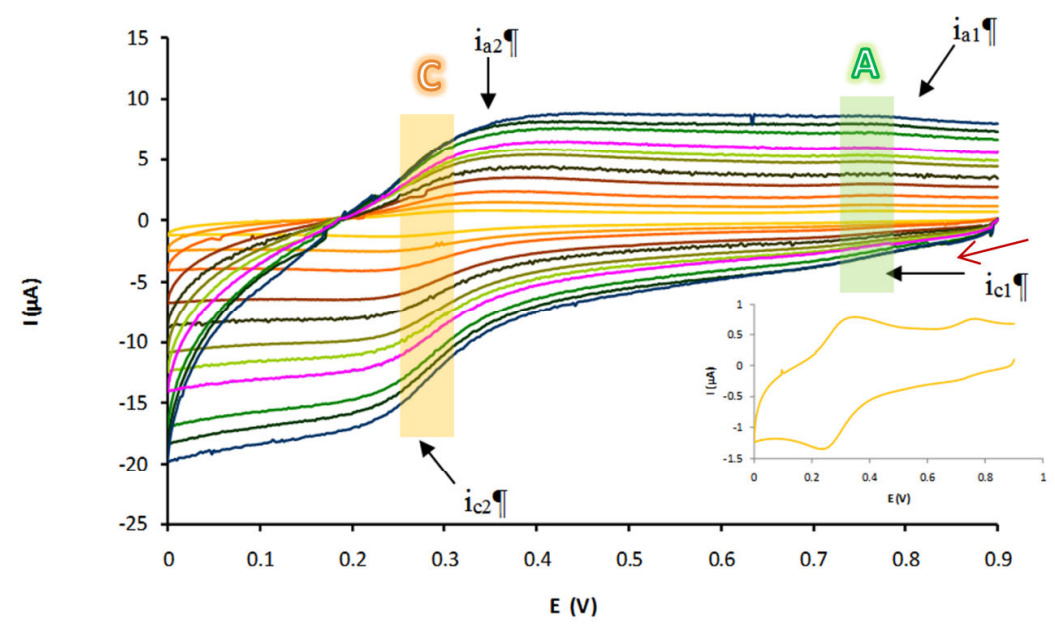

Figure 6. Cyclic voltammograms of complex $\mathbf{2}^{\mathbf{2}}$ in $0.1 \mathrm{M} \mathrm{CF}_{3} \mathrm{COOH}$ aqueous solution at $\mathrm{pH}=1.0$, scanning cathodically, and applying an initial equilibration time of 3 minutes at $0.90 \mathrm{~V}$. Scan rates: 20, 50, 100, 200, 300, 400, 500, 700, 800, 900 and $1000 \mathrm{mV} / \mathrm{s}$. The red arrow indicates the scanning direction $\mathrm{i}_{\mathrm{a} 1}$ : anodic peak intensity of the $\mathrm{Ru}(\mathrm{III} / \mathrm{II})-\mathrm{N}_{5}$ process; $\mathrm{i}_{\mathrm{a} 2}$ : anodic peak intensity of the $\mathrm{Ru}(\mathrm{III} / \mathrm{II})-\mathrm{ON} \mathrm{N}_{4}$ process; $\mathrm{i}_{\mathrm{cl}}$ : cathodic peak intensity of the $\mathrm{Ru}(\mathrm{III} / \mathrm{II})-\mathrm{N}_{5}$ process; $\mathrm{i}_{\mathrm{c} 1}$ : cathodic peak intensity of the $\mathrm{Ru}(\mathrm{III} / \mathrm{II})-\mathrm{ON} \mathrm{N}_{4}$ process. Inset: $\mathrm{CV}$ at scan rate of $20 \mathrm{mV} / \mathrm{s}$

The complete thermodynamic cycle associated with this linkage isomerization is presented in Scheme 3. All the thermodynamic and kinetic parameters involved in this cycle can be potentially extracted experimentally from CV measurements as we and other have shown for related systems. ${ }^{2,4}$ However in the present case the intensities of the waves involved are weak and wide and thus it is practically impossible to obtain reliable data. For this reason we have turned to DigiSim, ${ }^{31}$ a CV simulation package, in order to computationally extract the mentioned thermodynamic and kinetic parameters (See supporting information figure S17). 
Scheme 3. Thermodynamic cycle for the linkage isomerization process taking place upon the electrochemical oxidation of $\mathbf{2}^{2+}$ at $\mathrm{pH}=1.0$.

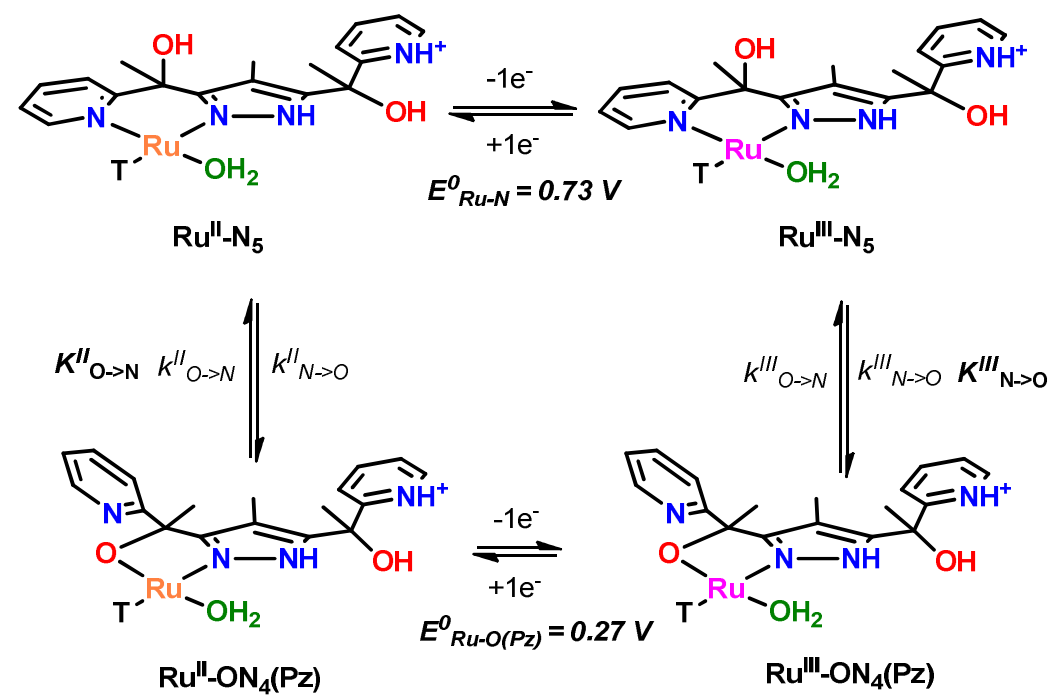

These parameters are presented in Table 1 together with those of related complexes, [Ru(bpy-py-OH)(4'-(pyrrolidin-1-yl)$2,2^{\prime}: 6^{\prime}, 2^{\prime \prime}$-terpyridine $\left.)\right]^{2+}, \mathbf{3}^{2+}$, and $\left[\mathrm{Ru}(\mathrm{bpy}-\mathrm{py}-\mathrm{OH})\left(4^{\prime}-(p \text {-tolyl)-2,2':6',2"-terpyridine })\right]^{2+} \mathbf{4}^{2+}\right.$, previously reported in the literature, where the $\mathrm{N}->\mathrm{O}$ linkage isomerization is also described for the bpy-py-OH ligand (see Chart 1 for a drawing). It is interesting to see that while the equilibrium constants $K_{\mathrm{O} \rightarrow \mathrm{N}}^{I I}=6.7 \cdot 10^{6}$ and $K_{N \rightarrow \mathrm{O}}^{I I I}=8.9$ are relatively similar, the kinetic rate constants are about two to four orders of magnitude smaller, manifesting the fact that this process is very slow for $2^{2+}$. The latter could be ascribed to the $\mathrm{Ru}-\mathrm{N}_{5}-\mathrm{H}_{2} \mathrm{O}$ nature of the $\mathbf{2}^{2+}$, whereas the reported ones are based on Ru- $\mathrm{N}_{6}$ type of coordination.

Table 1. Thermodynamic and Kinetic Parameters for the Electrochemically Induced Linkage Isomerization of $\mathbf{2}^{\mathbf{2 +}}$ and Related Systems. ${ }^{\text {a }}$

\begin{tabular}{llll}
\hline & $\mathbf{2}^{2+}$ & $\mathbf{3}^{2+, \mathbf{c}}$ & $\mathbf{4}^{2+, \mathbf{c}}$ \\
\hline $\boldsymbol{E}_{1 / 2}, \mathbf{N}(\mathbf{V})^{\mathbf{b}}$ & 0.73 & 0.755 & 0.972 \\
$\boldsymbol{E}_{1 / 2}, \mathbf{O}(\mathbf{V})^{\mathbf{b}}$ & 0.27 & 0.305 & 0.465 \\
$\boldsymbol{K}_{\mathbf{O}>\mathbf{N}}^{I I}$ & $6.7 \cdot 10^{6}$ & $3.4 \cdot 10^{6}$ & $2.1 \cdot 10^{6}$ \\
$\boldsymbol{K}^{I I}{ }_{\mathbf{N} \rightarrow \mathbf{O}}$ & 8.9 & 12 & 200 \\
$\boldsymbol{k}_{\mathbf{O} \rightarrow \mathbf{N}}^{I}\left(\mathbf{s}^{-1}\right)$ & 0.01 & 500 & 800 \\
$\boldsymbol{k}_{\mathbf{N} \rightarrow \mathbf{O}}\left(\mathbf{s}^{-1}\right)$ & $7.4 \cdot 10^{-7}$ & $1.47 \cdot 10^{-4}$ & $3.81 \cdot 10^{-4}$ \\
$\boldsymbol{k}_{\mathbf{O} \rightarrow \mathbf{N}}^{I I}\left(\mathbf{s}^{-1}\right)$ & 0.03 & 1.25 & 1.25 \\
$\boldsymbol{k}^{I I I}{ }_{\mathbf{N}>\mathbf{O}}\left(\mathbf{s}^{-1}\right)$ & 0.30 & 15 & 250 \\
\hline
\end{tabular}

${ }^{a}$ aqueous solution $(\mathrm{pH}=1)$ at $298 \mathrm{~K} .{ }^{\mathrm{b}}$ potential referenced $v s$. SSCE. ${ }^{\mathrm{c}} \mathbf{3}^{2+}$ is $\left[\mathrm{Ru}(\text { bpy-py-OH)(4'-(pyrrolidin-1-yl)-2,2':6',2"-terpyridine) }]^{2+}\right.$ and $4^{2+}$ is [Ru(bpy-py-OH)(4'-(p-tolyl)-2,2':6',2"-terpyridine $)]^{2+}$ described both in reference $4 \mathrm{a}$. 
Experiments to determine the $\mathrm{pH}$-dependence of the $\mathrm{Ru}(\mathrm{III} / \mathrm{II})$ redox for $\mathbf{2}^{\mathbf{2}+}$ from $\mathrm{pH} 0$ to 7 have been carried out and corresponding Pourbaix diagram is presented in Figure $7 \mathrm{a}$ where the different proton content of the dominant species is specified. The vertical lines indicate the $\mathrm{pKa}$ 's involved.

(a)

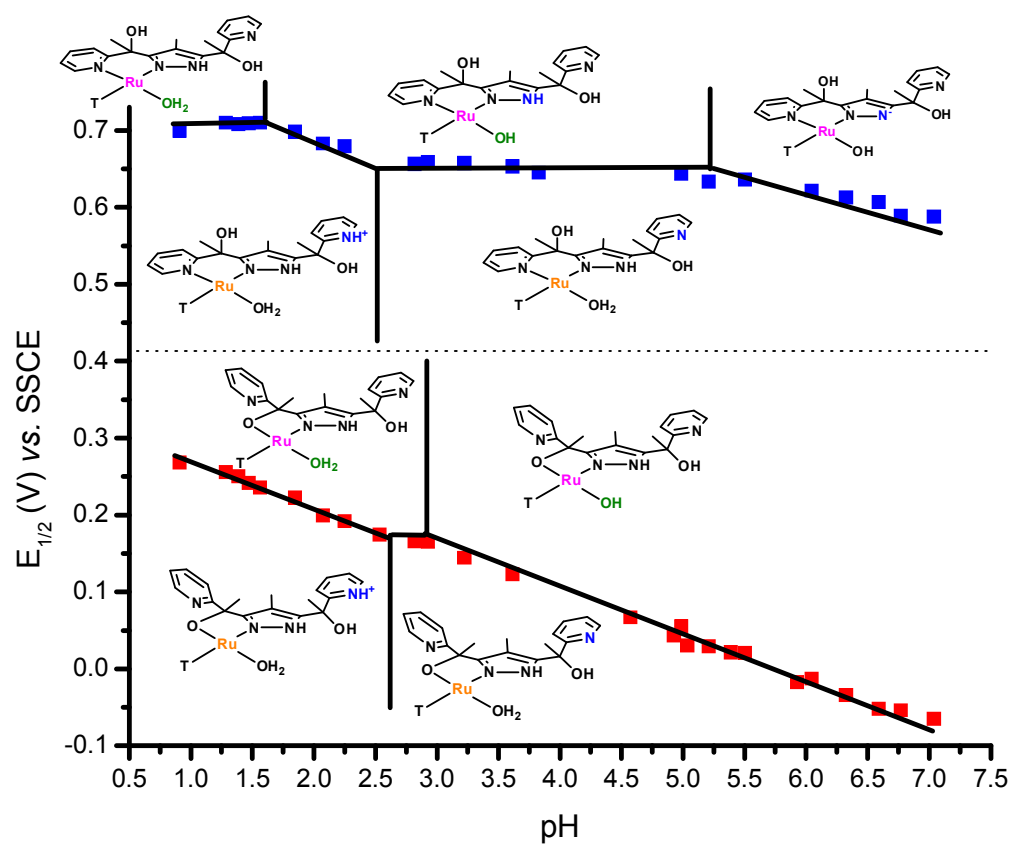

(b)

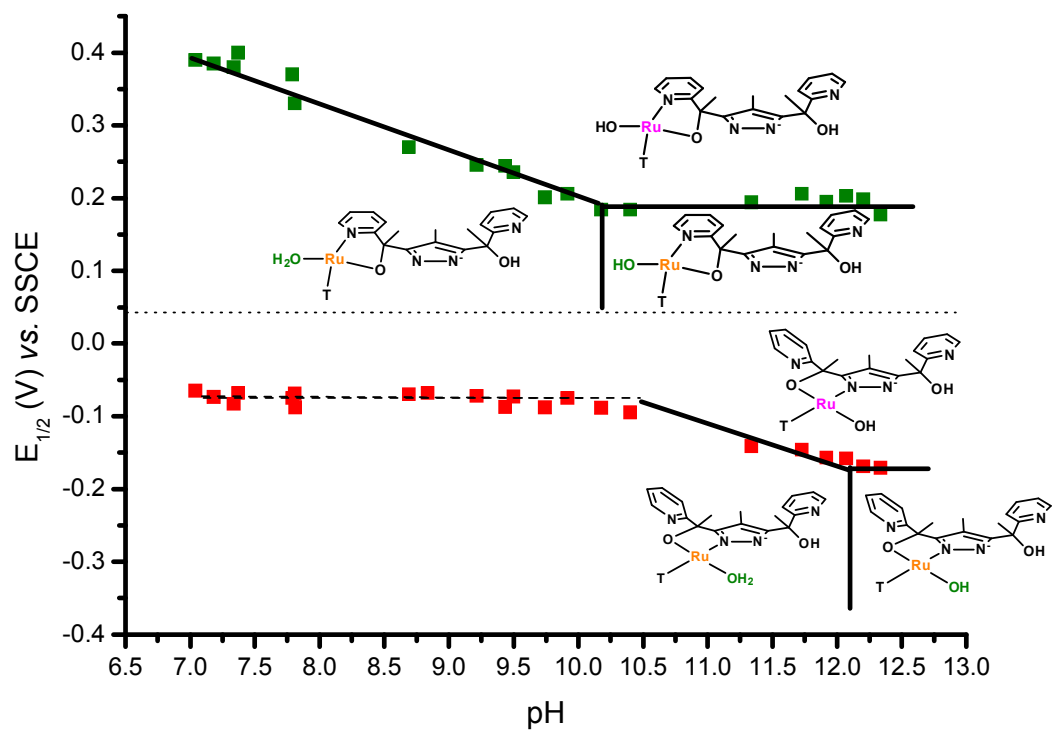

Figure 7. Pourbaix diagrams for the different isomers of complex $\mathbf{2}^{2+}$. (a) $\mathrm{pH}$ range 1-7, (b) $\mathrm{pH}$ range 712. The colored moiety is involved in the proton change. Color codes: Ru(III), pink; Ru(II) orange. 
Above $\mathrm{pH}$ 7, and as previously shown in the NMR, new isomeric species are generated. A CV (Figure 8) at this $\mathrm{pH}$ region indicates that the Ru-ON $\mathrm{ON}_{4}(\mathrm{Pz})$ species still exists, as shown by the continuity of the III/II redox couple over pH, but a new set of waves at higher redox potentials appears (Figure $7 \mathrm{~b}$ and Figure 8 wave E).

(a)

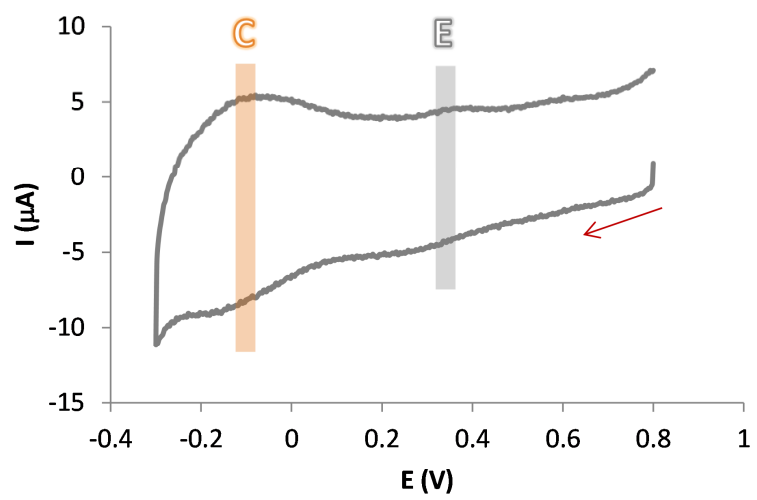

(b)

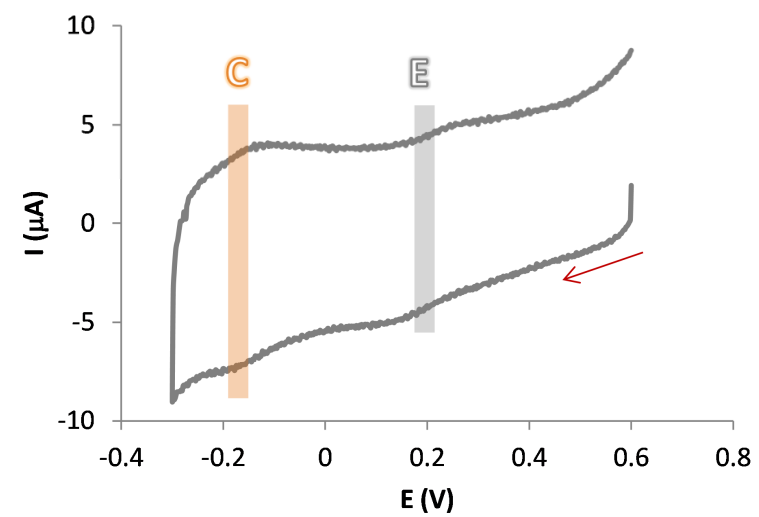

Figure 8. Cyclic voltammogram of complex $\mathbf{2}^{2+}$ at scan rate of $100 \mathrm{mV} / \mathrm{s}$ scanning cathodically with 3 minutes equilibration time at: (a) $0.80 \mathrm{~V}$ at $\mathrm{pH}=8.0$ and (b) $0.60 \mathrm{~V}$ at $\mathrm{pH}=12.0$. The red arrow indicates the scanning direction

We associate this new waves to the $\mathrm{Ru}-\mathrm{ON}_{4}(\mathrm{py})\left(2^{2+}\right)$ isomer (coordination to $\mathrm{Ru}$ through one hydroxyl oxygen an four nitrogen atoms: three from the trpy and one from the pyridyl group of Hpbl) depicted in the right hand side of Figure 9, where the pyrazole $\mathrm{N}$ is exchanged by the pyridyl ring maintaining the alkoxy coordination.

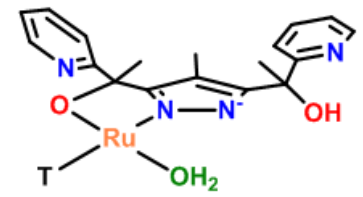

$\mathrm{Ru}^{\mathrm{II}}-\mathrm{ON}_{4}(\mathrm{Pz})$

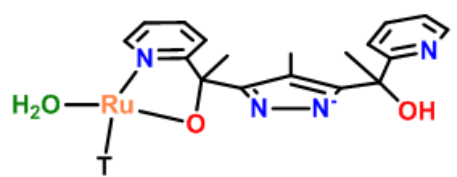

$\mathrm{Ru}^{\mathrm{II}}-\mathrm{ON}_{4}(\mathrm{Py})$

Figure 9. Drawing of the two coexisting isomers for complex $\mathbf{2}^{2+}$ in the $\mathrm{pH}$ range $7-12$.

The assignment is consistent with the monomeric nature obtained from the DOSY NMR experiment and the increased redox potential with regard to $\mathrm{Ru}-\mathrm{ON}_{4}(\mathrm{Pz})$ isomer, due to the replacement of a the anionic pyrazolate moiety by a neutral pyridyl coordinating group from the same Hbpl ligand. In Table 2 are gathered selected thermodynamic parameters for all the complexes described in the present work together with those of related complexes reported in the literature for purposes of comparison. 
Table 2. Electrochemical Data $(\mathrm{pH}=1.0)$ for the Ru-aqua Complexes Described in this Work and Others for Purposes of Comparison.

\begin{tabular}{cccccc}
\hline Entry & Complex $^{\mathrm{a}}$ & $\begin{array}{c}{ }^{\mathrm{b}} E_{1 / 2} \\
(\mathrm{III} / \mathrm{II})\end{array}$ & $\begin{array}{c}{ }^{\mathrm{b}} E_{1 / 2} \\
(\mathrm{IV} / \mathrm{III})\end{array}$ & $\Delta E$ & ref \\
\hline 1 & {$\left[\mathrm{Ru}^{\mathrm{II}}\left(\mathrm{N}_{5}\right) \mathrm{H}_{2} \mathrm{O}\right]^{2+}, \mathbf{2}^{2+}$} & 0.72 & 0.93 & 210 & $\mathrm{e}$ \\
2 & {$\left[\mathrm{Ru}^{\mathrm{II}}(\operatorname{trpy})(\mathrm{bpy}) \mathrm{OH}_{2}\right]^{2+}$} & 0.81 & 1.10 & 290 & $5 \mathrm{e}$ \\
3 & $i n-\left[\mathrm{Ru}^{\mathrm{II}}(\mathrm{Hbpp})(\operatorname{trpy}) \mathrm{OH}_{2}\right]^{2+}$ & 0.66 & -- & -- & $2 \mathrm{f}$ \\
4 & {$\left[\mathrm{Ru}^{\mathrm{II}}\left(\mathrm{ON}_{4}(\mathrm{Pz})\right) \mathrm{H}_{2} \mathrm{O}\right]^{2+}$} & 0.24 & -- & -- & $\mathrm{e}$ \\
5 & $\left\{\left[\mathrm{Ru}^{\mathrm{II}}(\operatorname{trpy})\left(\mathrm{H}_{2} \mathrm{O}\right)\right]_{2}\left(\mu-\mathrm{dcpz}^{2+}\right]\right\}^{+}$ & 0.20 & & & $7 \mathrm{a}$ \\
6 & {$\left[\mathrm{Ru}^{\mathrm{II}}\left(\mathrm{ON} \mathrm{ON}_{4}(\mathrm{Py})\right) \mathrm{H}_{2} \mathrm{O}\right]^{2+c}$} & 0.38 & -- & -- & $\mathrm{e}$ \\
7 & $c i s-\left[\mathrm{Ru}^{\mathrm{II}}(\operatorname{trpy})(\mathrm{pic}) \mathrm{OH}_{2}\right]^{+, \mathrm{c}}$ & 0.38 & 0.56 & 180 & $29 \mathrm{~b}$ \\
\hline
\end{tabular}

${ }^{a}$ Ligand abbreviations used: trpy $=2,2^{\prime}: 6$ ',2"'terpyridine, bpy $=2,2$ 'bipyridine, $\mathrm{Hbpp}=3,5$-bis(2-pyridyl)pyrazole, pic $=$ picolinate, $\mathrm{dcpz}=$ pyrazole-3,5-dicarboxylate ligand. ${ }^{\text {b }}$ redox potentials in volts are reported with regard to the SSCE reference electrode. ${ }^{c}$ measured at $\mathrm{pH}=7$ (phosphate buffer). ${ }^{\mathrm{d}} \Delta E=E_{1 / 2}(\mathrm{IV} / \mathrm{III})-E_{1 / 2}$ (III/II) in $\mathrm{mV}$. ${ }^{\mathrm{e}}$ this work

The different geometries and relative stability among the linkage isomers of $\mathbf{2}^{\mathbf{2}}$ at $\mathrm{pH}=4.0$ and at oxidation state II and III, have been further analyzed by means of DFT calculations. For $\mathrm{Ru}(\mathrm{II})$ (Figure 10, top) the $\mathrm{Ru}^{\mathrm{II}}-\mathrm{N}_{5}$ coordination environment is clearly favored in agreement with the HSAB-Pearson theory, ${ }^{3}$ with the corresponding $\mathrm{Ru}^{\mathrm{II}}-\mathrm{ON} \mathrm{N}_{4}(\mathrm{Pz})$ and $\mathrm{Ru}^{\mathrm{II}}-\mathrm{ON}{ }_{4}(\mathrm{Py})$ linkage isomers at 24.6 and $21.7 \mathrm{kcal} \mathrm{mol}^{-1}$ higher in energy, respectively. At oxidation sate III (Figure 5, bottom) the Ru ${ }^{\text {III }}$ $\mathrm{ON}_{4}(\mathrm{Pz})$ and $\mathrm{Ru}^{\mathrm{III}}-\mathrm{ON}_{4}(\mathrm{Py})$ species are thermodynamically favored versus $\mathrm{Ru}^{\mathrm{III}}-\mathrm{N}_{5}$ by 0.5 and $5.9 \mathrm{kcal}^{\mathrm{mol}}{ }^{-1}$, respectively, also in agreement with the HSAB-Pearson theory, although now the relative energies are much closer to one another. The higher relative stability of the $\mathrm{Ru}^{\mathrm{II}}-\mathrm{ON}_{4}(\mathrm{Py})$ species with respect to the $\mathrm{Ru}^{\mathrm{II}}-\mathrm{ON}_{4}(\mathrm{Py})$ one is due to the geometrical disposition in cis of the Ru-O moieties as well as the rather strong H-bond between a hydrogen atom of the aquo ligand and the oxygen of the Ru-O moiety in cis $(2.070 \AA)$. While the $\mathrm{Ru}^{\mathrm{III}}-\mathrm{ON}_{4}(\mathrm{Py})$ is the most thermodynamically favored at this oxidation state and $\mathrm{pH}$ according to DFT, TS energies might be responsible for the generation of the $\mathrm{Ru}^{\mathrm{III}}-\mathrm{ON}_{4}(\mathrm{Pz})$ isomer which is the experimentally observed species. This is important to underline here since as mentioned at the beginning of this section linkage isomerization process observed here are very slow. A full set of coordinates and absolute energies (in a.u.) for all the DFT optimized complexes are presented in the supporting information (table S2). 

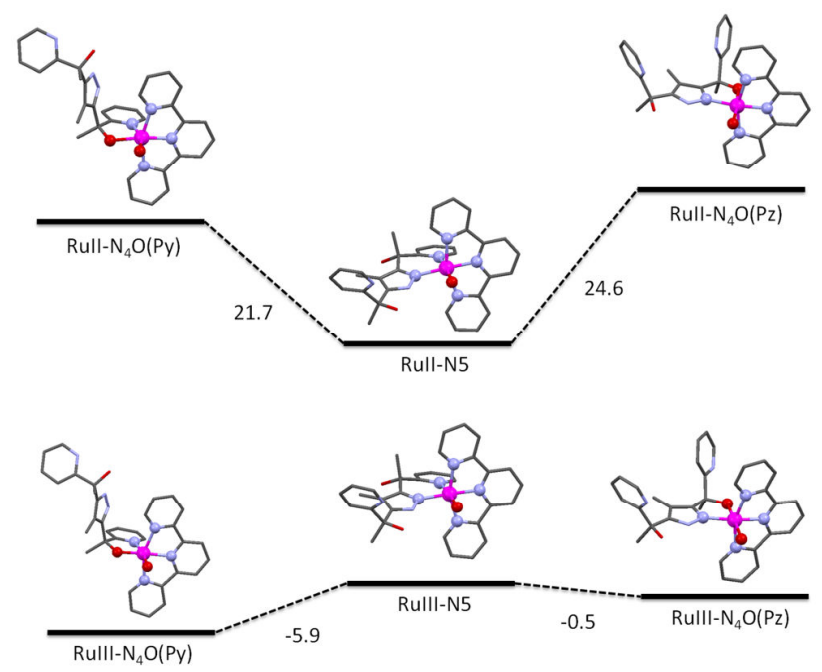

Figure 10. Relative energy diagram for the DFT-optimized geometries of the cationic moieties of the linkage isomers of $\mathbf{2}^{\mathbf{2}}$ at $\mathrm{pH}=4.0$ : $\mathrm{Ru}(\mathrm{II})$ (top) and $\mathrm{Ru}(\mathrm{III})$ (bottom). Energies are given in $\mathrm{kcal} \mathrm{mol}^{-1}$. Color codes: Ru, magenta; O, red; N, blue; $\mathrm{C}$, gray ( $\mathrm{H}$ atoms are omitted for the sake of clarity).

\section{Conclusions}

A new tetradentate ditopic ligand, Hbpl, with multiple $\mathrm{N}$ - and O-coordination sites has been prepared and fully characterized. The ligand is designed so that $\mathrm{N}$ - or O-coordination can be chosen depending of the nature and the oxidation state of the metal used. Mononuclear Ru-Cl, $\mathbf{1}^{+}$, and Ru-aqua, $\mathbf{2}^{2+}$, complexes have been prepared and spectroscopic and electrochemically characterized. Both complexes contain the tridentate meridional trpy ligand together with Hbpl, completing the expected octahedral coordination. Given the multiple coordination sites of the Hbpl ligand, NMR has been crucial to fully characterize the structure of the complexes in solution at oxidation state II. Furthermore the HMBC-N NMR experiment has been proven to be a very powerful tool for the diagnosis of coordinated $v s$. non-coordinated $\mathrm{N}$ atoms for Hbpl, which can be obviously extended to related complexes where this might be needed.

The existence of linkage isomerization fostered by the oxidation of $\mathrm{Ru}(\mathrm{II})$ to $\mathrm{Ru}(\mathrm{III})$ in $\mathbf{2}^{2+}$, has been clearly shown by $\mathrm{CV}$ and the thermodynamic and kinetic parameters related to the thermodynamic cycle have been extracted using DigiSim, an electrochemistry simulation package. Here the alkoxo group replaces the initially coordinated pyridyl group generating the $\mathrm{N}->\mathrm{O}$ isomerization that we labeled as $\left[\mathrm{Ru}\left(\mathrm{N}_{5}\right)\left(\mathrm{H}_{2} \mathrm{O}\right)\right]^{2+}$ to $\left[\mathrm{Ru}\left(\mathrm{ON}_{4}(\mathrm{pz})\right)\left(\mathrm{H}_{2} \mathrm{O}\right)\right]^{2+}$ (See Scheme 3). Electrochemistry and NMR also reveal the presence of a new isomer in basic solutions, where the pyrazolyl coordinating group is replaced by the pyridyl group, thus forming $\left[\mathrm{Ru}\left(\mathrm{ON}_{4}(\mathrm{py})\right)\left(\mathrm{H}_{2} \mathrm{O}\right)\right]^{2+}$, as indicated in Figure 9. Finally geometrical optimizations have also been carried out by means of DFT calculations that provide further support for all the isomers observed experimentally. 


\section{ASSOCIATED CONTENT}

Supporting Information. Computational details and further spectroscopic (1D and 2D NMR) and electrochemical measurements for the reported complexes. This material is available free of charge via the Internet at http://pubs.acs.org."

\section{AUTHOR INFORMATION}

\section{Corresponding Author}

*E-mail: xavier.sala@uab.cat (X.S.), 1luis.escriche@uab.cat (L.E.), allobet@iciq.es (A.L.)

\section{ACKNOWLEDGMENT}

Support from MINECO (CTQ2011-26440, CTQ-2013-49075-R and CTQ2011-23156-C02-02) is gratefully acknowledged. L.F. is grateful for the award of a PIF doctoral grant from UAB. AP is grateful to the European Commission (CIG09-GA2011-293900), and the Spanish MINECO (Ramón y Cajal contract RYC-2009-05226).

\section{REFERENCES}

[1] (a) Wagenknecht, P. S.; Ford, P. C. Coord. Chem. Rev. 2011, 255, 591-616. (b) Jurow, M.; Schuckman, A. E.; Batteas, J. D.; Drain, C. M. Coord. Chem. Rev. 2010, 254, 2297-2310. (c) Ceroni, P. Electrochemistry of functional supramolecular systems; Wiley: Hoboken N.J., 2010. (d) De Salvo, B.; Molas, G.; Perniola, L.; Jahan, C.; Buckley, J.; Jalaguier, E.; Gely, M. In ECS Transactions; Vienna, Austria, 2009; 151-162. (e) Akita, M.; Koike, T. Dalton Trans. 2008, 3523. (f) Nishihara, H.; Kanaizuka, K.; Nishimori, Y.; Yamanoi, Y. Coord. Chem. Rev. 2007, 251, 2674-2687. (g) Baranoff, E.; Collin, J.; Furusho, J.; Furusho, Y.; Laemmel, A.; Sauvage, J. Inorg. Chem. 2002, 41, 1215-1222. (h) Ballardini, R.; Balzani, V.; Credi, A.; Gandolfi, M. T.; Venturi, M. Int. J. Photoenerg. 2001, 3, 63-77. (i) Ashton, P. R.; Ballardini, R.; Balzani, V.; Credi, A.; Dress, K. R.; Ishow, E.; Kleverlaan, C. J.; Kocian, O.; Preece, J. A.; Spencer, N.; Stoddart, J. F.; Venturi, M.; Wenger, S. Chem. Eur. J. 2000, 6, 3558-3574.

[2] (a) Roeser, S.; Maji, S.; Benet-Buchholz, J.; Pons, J.; Llobet A. Eur. J. Inorg. Chem. 2013, 2013, 232-240.(b) J. BenetBuchholz, P. Comba, A. Llobet, S. Roeser, P. Vadivelu, S. Wiesner, Dalton T. 2010, 39, 3315-3320.(c) Hamaguchi, T.; Ujimoto, K.; Ando, I. Inorg. Chem. 2007, 46, 10455-10457. (d) Rachford, A. A.; Rack, J. J. J. Am. Chem. Soc. 2006, 128, 14318-14324. (e) Butcher, D. P.; Rachford, A. A.; Petersen, J. L.; Rack, J. J. Inorg. Chem. 2006, 45, 9178-9180. (f) Sens, 
C.; Rodríguez, M.; Romero, I.; Llobet, A.; Parella, T.; Sullivan, B. P.; Benet-Buchholz, J. Inorg. Chem. 2003, 42, $2040-2048$. (g) Atolagbe, P. O.; Taylor, K. N.; Wood, S. E.; Rheingold, A. L.; Harper, L. K.; Bayse, C. A.; Brunker, T. J. Inorg. Chem.

\section{3, 52, 1170-1172.}

[3] Pearson, R. G. J. Am. Chem. Soc. 1963, 85, 3533-3539.

[4] (a) Johansson, O.; Johannissen, L.; Lomoth, R. Chem.-Eur. J. 2009, 15, 1195-1204. (b) Johansson, O.; Lomoth, R. Inorg. Chem. 2008, 47, 5531-5533. (c) Johansson, O.; Lomoth, R. Chem. Commun. 2005, 1578-1580.

[5] (a) Serrano, I.; López, M. I.; Ferrer, I.; Poater, A.; Parella, T.; Fontrodona, X.; Solà, M.; Llobet, A.; Rodríguez, M.; Romero, I. Inorg. Chem. 2011, 50, 6044-6054. (b) Prades, A.; Peris, E.; Albrecht, M. Organometallics 2011, 30, 1162-1167. (c) Roeser, S.; Farràs, P.; Bozoglian, F.; Martínez-Belmonte, M.; Benet-Buchholz, J.; Llobet, A. ChemSusChem 2011, 4, 197207.(d) Tada, M.; Muratsugu, S.; Kinoshita, M.; Sasaki, T.; Iwasawa, Y. J. Am. Chem. Soc. 2010, 132, 713-724. (e) Dakkach, M.; López, M. I.; Romero, I.; Rodríguez, M.; Atlamsani, A.; Parella, T.; Fontrodona, X.; Llobet, A. Inorg. Chem. 2010, 49, 7072-7079. (f) Benet-Buchholz, J.; Comba, P.; Llobet, A.; Roeser, S.; Vadivelu, P.; Wiesner, S. Dalton Trans. 2010, 39, 3315. (g) Jiang, G.; Chen, J.; Thu, H.; Huang, J.; Zhu, N.; Che, C. Angew. Chem. Int. Ed. 2008, 47, 6638-6642. (h) Sala, X.; Santana, N.; Serrano, I.; Plantalech, E.; Romero, I.; Rodríguez, M.; Llobet, A.; Jansat, S.; Gómez, M.; Fontrodona, X. Eur. J. Inorg. Chem. 2007, 5207-5214. (i) Serrano, I.; Sala, X.; Plantalech, E.; Rodríguez, M.; Romero, I.; Jansat, S.; Gómez, M.; Parella, T.; Stoeckli-Evans, H.; Solans, X.; Font-Bardia, M.; Vidjayacoumar, B.; Llobet, A. Inorg. Chem. 2007, 46, 53815389. (j) Rodríguez, M.; Romero, I.; Sens, C.; Llobet, A. J. Mol. Catal. A-Chem. 2006, 251, 215-220. (k) Punniyamurthy, T.; Velusamy, S.; Iqbal, J. Chem. Rev. 2005, 105, 2329-2364. (1) Catalano, V. J.; Heck, R. A.; Immoos, C. E.; Öhman, A.; Hill, M. G. Inorg. Chem. 1998, 37, 2150-2157. (m) Sens, C.; Romero, I.; Rodríguez, M.; Llobet, A.; Parella, T.; Benet-Buchholz, J. J. Am. Chem. Soc. 2004, 126, 7798-7799. (n) Rodríguez, M. Electrochim. Acta 2003, 48, 1047-1054. (o) Marmion, M. E.; Takeuchi, K. J. J. Am. Chem. Soc. 1988, 110, 1472-1480. (p) Marmion, M. E.; Takeuchi, K. J. J. Am. Chem. Soc. 1986, 108, 510-511.

[6] (a) Meyer, T. J.; Huynh, M. H. V. Inorg. Chem. 2003, 42, 8140-8160. (b) Dovletoglou, A.; Adeyemi, S. A.; Meyer, T. J. Inorg. Chem. 1996, 35, 4120-4127. (c) Suen, H. F.; Wilson, S. W.; Pomerantz, M.; Walsh, J. L. Inorg. Chem. 1989, 28, 786791. (d) Roecker, L.; Kutner, W.; Gilbert, J. A.; Simmons, M.; Murray, R. W.; Meyer, T. J. Inorg. Chem. 1985, 24, 37843791. (e) Takeuchi, K. J.; Thompson, M. S.; Pipes, D. W.; Meyer, T. J. Inorg. Chem. 1984, 23, 1845-1851. (f) Binstead, R. A.; Moyer, B. A.; Samuels, G. J.; Meyer, T. J. J. Am. Chem. Soc. 1981, 103, 2897-2899. (g) Moyer, B. A.; Meyer, T. J. Inorg. Chem. 1981, 20, 436-444. (h) Moyer, B. A.; Meyer, T. J. J. Am. Chem. Soc. 1978, 100, 3601-3603. 
[7] (a) C. Di Giovanni, A. Poater, J. Benet-Buchholz, L. Cavallo, M. Solà, A. Llobet, Chem.-Eur. J. 2014, 20, 3898-3902.

(b) Di Giovanni, C.; Vaquer, L.; Sala, X.; Benet-Buchholz, J.; Llobet A. Inorg. Chem. 2013, 52, 4335-4345.

[8] García-Antón, J.; Bofill, R.; Escriche, L.; Llobet, A.; Sala, X. Eur. J. Inorg. Chem. 2012, 4775-4789 and references therein.

[9] (a) Concepcion, J. J.; Tsai, M.; Muckerman, J. T.; Meyer, T. J. J. Am. Chem. Soc. 2010, 132, 1545-1557. (b) Bozoglian, F.; Romain, S.; Ertem, M. Z.; Todorova, T. K.; Sens, C.; Mola, J.; Rodríguez, M.; Romero, I.; Benet-Buchholz, J.; Fontrodona, X.; Cramer, C. J.; Gagliardi, L.; Llobet, A. J. Am. Chem. Soc. 2009, 131, 15176-15187. (c) Cape, J. L.; Siems, W. F.; Hurst, J. K. Inorg. Chem. 2009, 48, 8729-8735. (d) Nunes, G.; Alexiou, A.; Toma, H. J. Catal. 2008, 260, 188-192. (e) Cape, J. L.; Hurst, J. K. J. Am. Chem. Soc. 2008, 130, 827-829. (f) Hurst, J. Coord. Chem. Rev. 2005, 249, 313-328. (g) Bennett, S.; Brown, S. M.; Conole, G.; Kessler, M.; Rowling, S.; Sinn, E.; Woodward, S. J. Chem. Soc., Dalton Trans. $1995,367$.

[10] (a) Francàs, L.; Sala, X.; Escudero-Adán, E.; Benet-Buchholz, J.; Escriche, L.; Llobet, A. Inorg. Chem. 2011, 50, 27712781. (b) Francàs, L.; Sala, X.; Benet-Buchholz, J.; Escriche, L.; Llobet, A. ChemSusChem 2009, 2, 321-329.

[11] Sullivan, B.P.; Calvert, J.M.; Meyer, T. J. Inorg.Chem. 1980, 19, 1404.

[12] (a) Sachse, A.; Penkova, L.; Noël, G.; Dechert, S.; Varzatskii, O.; Fritsky, I.; Meyer, F. Synthesis 2008, 800-806. (b) Ghosh, A.; Bischoff, A.; Cappiello, J. Eur. J. Org. Chem. 2003, 821-832. (c) Meth-Cohn, O.; Vuorinen, E.; Modro, T. A. J. Org. Chem. 1989, 54, 4822-4827. (d) Wulfman, D. Tetrahedron 1976, 32, 1257-1265.

[13] Data collection with SMART: Version 5.631, 1997-2002 Bruker Advanced X-ray Solutions.

[14] Data reduction with Bruker SAINT+ Version 6.36A, 2001

[15] SADABS: V.2.10(2003); Bruker (2001). Bruker AXS Inc., Madison, Wisconsin, USA. Blessing, Acta Cryst. (1995) A5 $33-38$.

[16] Structure solution and model refinement with SHELXTL Version 6.14, 2000-2003. Bruker AXS Inc., Madison, Wisconsin, USA.

[17] (a) Becke, A. D. J. Chem. Phys. 1993, 98, 5648-5652. (b) Perdew, J. P.; Wang, Y. Phys. ReV. B 1992, 45, $13244-13249$. [18] Gaussian 09, Revision D.01, Frisch, M. J.; Trucks, G. W.; Schlegel, H. B.; Scuseria, G. E.; Robb, M. A.; Cheeseman, J. R.; Scalmani, G.; Barone, V.; Mennucci, B.; Petersson, G. A.; Nakatsuji, H.; Caricato, M.; Li, X.; Hratchian, H. P.; Izmaylov, A. F.; Bloino, J.; Zheng, G.; Sonnenberg, J. L.; Hada, M.; Ehara, M.; Toyota, K.; Fukuda, R.; Hasegawa, J.; Ishida, M.; Nakajima, T.; Honda, Y.; Kitao, O.; Nakai, H.; Vreven, T.; Montgomery, J. A., Jr.; Peralta, J. E.; Ogliaro, F.; Bearpark, M.; Heyd, J. J.; Brothers, E.; Kudin, K. N.; Staroverov, V. N.; Kobayashi, R.; Normand, J.; Raghavachari, K.; Rendell, A.; Bu- 
rant, J. C.; Iyengar, S. S.; Tomasi, J.; Cossi, M.; Rega, N.; Millam, N. J.; Klene, M.; Knox, J. E.; Cross, J. B.; Bakken, V.; Adamo, C.; Jaramillo, J.; Gomperts, R.; Stratmann, R. E.; Yazyev, O.; Austin, A. J.; Cammi, R.; Pomelli, C.; Ochterski, J. W.; Martin, R. L.; Morokuma, K.; Zakrzewski, V. G.; Voth, G. A.; Salvador, P.; Dannenberg, J. J.; Dapprich, S.; Daniels, A. D.; Farkas, Ö.; Foresman, J. B.; Ortiz, J. V.; Cioslowski, J.; Fox, D. J. Gaussian, Inc., Wallingford CT, 2009.

[19] Andrae, D.; Haussermann, U.; Dolg, M.; Stoll, H.; Preuss, H. Theor. Chim. Acta 1990, 77, 123-141. (b) Bergner, A.; Dolg, M.; Kuchle, W.; Stoll, H.; Preuss, H. Mol. Phys. 1993, 80, 1431-1444.

[20] Hehre, W. J.; Ditchfield, R.; Pople, J. A. J. Chem. Phys. 1972, 56, 2257-2261.

[21] Barone, V.; Cossi, M. J. Phys. Chem. A 1998, 102, 1995-2001.

[22] Zhao, Y.; Truhlar, D. Theor. Chem. Acc. 2008, 120, 215-241.

[23] Dunning, T. H. J. Chem. Phys. 1989, 90, 1007-1023.

[24] Tawa, G. J.; Topol, I. A.; Burt, S. K.; Caldwell, R. A.; Rashin, A. A. J. Chem. Phys. 1998, 109, 4852-4963.

[25] Rodríguez, M.; Romero, I.; Sens, C.; Llobet, A.; Deronzier, A., Electrochim. Acta 2003, 48, 1047-1054.

[26] (a) Roeser, S.; Farràs, P.; Bozoglian, F.; Martínez-Belmonte, M.; Benet-Buchholz, J.; Llobet, A. ChemSusChem 2011, 4, 197-207. (b) Sens, C.; Rodríguez, M.; Romero, I.; Llobet, A.; Parella, T.; Benet-Buchholz, J. Inorg. Chem. 2003, 42, 83858394.

[27] (a) Hu, Y.-Z.; Xiang, Q.; Thummel, R. P. Inorg. Chem. 2002, 41, 3423-3428. (b) Brown, D.; Muranjan, S.; Jang, Y.; Thummel, R. Org. Lett. 2002, 4, 1253-1256. (c) Wu, F.; Thummel, R. P. Inorg. Chim. Acta 2002, 327, 26-30. (d) Juris, A.; Prodi, L.; Harriman, A.; Ziessel, R.; Hissler, M.; El-Ghayoury, A.; Wu, F.; Riesgo, E. C.; Thummel, R. P. Inorg. Chem. 2000, 39, 3590-3598. (e) Wu, F.; Riesgo, E. C.; Thummel, R. P.; Juris, A.; Hissler, M.; El-Ghayoury, A.; Ziessel, R. Tet. Lett. 1999, 40, 7311-7314.

[28] (a) Rodríguez, M.; Romero, I.; Llobet, A.; Deronzier, A.; Biner, M.; Parella, T.; Stoeckli-Evans, H. Inorg. Chem. 2001, 40, 4150-4156. (b) Barkawi, K.; Llobet, A.; Meyer, T. J. J. Am. Chem. Soc. 1988, 110, 7751. (c) Llobet, A. Inorg. Chim. Acta 1994, $221,125-131$

[29] (a) Haga, M.; Dodsworth, E. S.; Lever, A. B. P. Inorg. Chem. 1986, 25, 447-453. (b) Wong, C.-Y.; Che, C.-M.; Chan, M. C. W.; Leung, K.-H.; Phillips, D. L.; Zhu, N. J. Am. Chem. Soc. 2004, 126, 2501. (c) Kannan, S.; Ramesh, R.; Liu, Y. J. Organomet. Chem. 2007, 692, 3380. (d) Raja, N.; Ramesh, R. Spectrochim. Acta Part A. 2010, 75, 713 
[30] (a) Takeuchi, K. J.; Thompson, M. S. ; Pipes, D. W.; Meyer, T. J. Inorg. Chem. 1984, 24, 3784-3791 (b) Llobet, A.; Doppelt, P.; Meyer, T. J. Inorg. Chem. 1988, 27, 514-520. (c) Cheng, W. C. ; Yu, W. Y. ; Cheung, K. K. ; Che, C. M. J. Chem. Soc. Dalton Trans. 1994, 57-62.

[31] DigiSim 3.03: BASi DigiSim ${ }^{\circledR}$ Simulation Software for Cyclic Voltammetry 


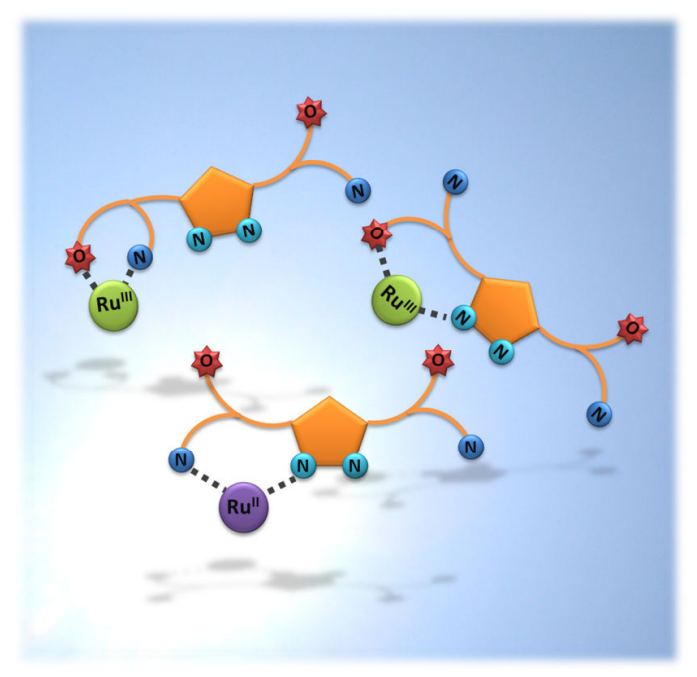

New mononuclear Ru complexes containing the Hpbl hemilabile ligand that can coordinate either by the $\mathrm{N}$ atoms or a mixing of $\mathrm{N}$ and $\mathrm{O}$ is reported and fully characterized. The conditions under which an N/O linkage interconversion occurs is described and followed by means of cyclic voltammetry. 